Article

\title{
French Postverbal Subjects: A Comparison of Monolingual, Bilingual, Trilingual, and Multilingual French
}

\author{
Laia Arnaus Gil * and Natascha Müller * \\ Fakultät 1, Romanische Sprachwissenschaft, Bergische Universität Wuppertal, Gaußstraße 20, \\ 42119 Wuppertal, Germany \\ * Correspondence: arnaus@uni-wuppertal.de (L.A.G.); nmueller@uni-wuppertal.de (N.M.); \\ Tel.: +49-202-439-2157 (L.A.G.); +49-202-439-2160 (N.M.)
}

Received: 13 November 2017; Accepted: 24 July 2018; Published: 28 July 2018

\begin{abstract}
Monolingual French children have been observed to pass through a stage which is characterized by the production of target-deviant postverbal subjects of the following type (Jansen 2015, p. 272): est tombé Philippe 'is fallen Philippe' (Philippe, 2;2,10), écrit bien celui-là 'writes well this one' (Philippe, 2;2,2) (De Cat 2002; Déprez and Pierce 1993; Ferdinand 1993, 1996; Friedemann [1993] 1994; Labelle and Valois 1996; Pierce 1989). Interestingly, bilingual children who acquire French together with German produce postverbal subjects to an extremely low degree in mean length of utterance (MLU)-phases compared with monolingual children (Jansen 2015). Arguably, they skip the postverbal subject phase and are accelerated with respect to monolingual children. In our study, we tested whether multilingualism can speed up the acquisition process in French. A production test with 62 multilingual children (starting at 2;7 acquiring two, three, or four L1s) was administered in Spain and Germany to elicit finite verbs and DP (Determiner Phrase) subjects in French. The children's proficiency in French was measured on the basis of the Peabody Picture Vocabulary Test (PPVT) (Dunn et al. 1993). In comparison with monolinguals studied in the literature, the bilingual children and the children who acquired more than two languages were accelerated with respect to the placement of subjects in the postverbal position. Although the multilingual children who ranked low in the PPVT exhibited all kinds of structures as responses to the test items that are characteristic of early French, such as null-subjects, root infinites and bare nouns, they did not use postverbal subjects. The absence of postverbal subjects was observed not only in children who acquired either German (or English) at the same time as French, as did the bilingual children in Jansen's (2015) study, but also in children who acquired, in addition to French, a Romance language like Spanish, Catalan, or Italian, all null-subject languages which allow postverbal subjects in the adult language. Following (Biberauer and Richards 2006), the extended projection principle (EPP) feature of $T$ (Tense) can be satisfied in different ways across languages: if a DP is necessary, which it is in adult French, it can be raised from Spec, vP (specifier of $v \mathrm{P}$, of the small-verb Phrase) to Spec,TP (specifier of Tense Phrase) (in which case the finite verb surfaces in T). This is the default of EPP satisfaction in T. It is this option which is facilitated and boosts the acquisition of the preverbal subject position in early bilingual, trilingual, and multilingual French. The result that the children who acquired a null-subject language such as Spanish also enjoyed an advantage in French, adult Spanish being a language that allows for postverbal subjects, indicates that it is plausible that the default character of DP-raising for EPP satisfaction, instantiated in all languages involved, is the reason for its high relevance in the early French of bilingual, trilingual, and multilingual children. If our analysis of the multilingual data is plausible, monolingual French children exhibit more variation in satisfying the EPP-feature (in T) than children who acquire one or more other languages in addition to French, an observation which goes back to (Meisel 1989).
\end{abstract}

Keywords: French; postverbal subjects; EPP satisfaction; cross-linguistic influence 


\section{Introduction}

Bilingual children who grow up with two languages from birth can separate them (cf. Genesee 1989; Lleó 2002; Lleó and Kehoe 2002; Meisel 1989), but the acquisition path is characterized by cross-linguistic influence. This influence characterizes bilingual phonology (Lleó 2016; Lleó and Rakow 2006), morphology (Nicoladis 1999, 2003), and syntax (Döpke 1992, 1997, 1998; Gawlitzek-Maiwald and Tracy 1996; Hulk and Müller 2000; Müller and Hulk 2001). Paradis and Genesee (1996) argue that it has two effects: delay and acceleration. Compared to delay effects, acceleration effects are understudied in early child bilingualism. They exist in bilingual German/English-Romance children (Kupisch 2006 for determiner realizations in German; Fernández Fuertes and Liceras 2010; Liceras et al. 2012 for copula realizations in English and for overt realization of subject pronouns in English; cf. Liceras and Fuertes 2018). Recently, Patuto et al. (2011) have considered whether these two effects, as has generally been assumed in the literature, are both rooted in cross-linguistic influence. Müller (2017) assumes that acceleration has a different source and is reminiscent of the bilingual advantage which is due to enhanced cognitive abilities.

This article will investigate whether acceleration effects are also present in children acquiring three or more languages from birth. The grammatical domain chosen, postverbal subjects in French, is accelerated in bilingual children (Jansen 2015). Since "trilingual children have to divide their exposure time across three languages and thus may have even more reduced input than many bilingual children, at least in one of their three languages" (Unsworth 2013, p. 40), the question we ask is whether, given a decreased amount of input in each language, the development of the grammatical domain is delayed as compared to bilingual as well as to monolingual French children. As a counterpoint to decreased input quantity, the trilingual child experiences increased input diversity. Thus, "infants exposed to two or more languages from birth are innately prepared to phonetically process and learn regularities from multiple native languages, and multilingualism does not delay nor compromise the development of linguistic representation" (Montanari 2010a, p. 135). This might suggest that the exposure to two or more languages from birth could lead multilingual children to experience acceleration effects.

The article is structured as follows: Section 2 gives an overview of existing studies on early child trilingualism. Section 3 describes the phenomenon observed in monolingual and bilingual French children, namely postverbal subjects. Section 4 is devoted to the present study. Elicited production was administered to 18 bilingual, 38 trilingual and 6 multilingual children who spoke French as one of their native languages. Section 5 discusses the results and concludes the article.

\section{Issues in Early Child Multilingualism}

The study of early child trilingualism is still in its infancy (cf. Unsworth 2013, p. 41ff), a statement which goes back to Quay (2001, p. 149), Hoffmann (2001, p. 13), Barnes (2006, p. 28) and is still valid in 2017 (but see the works of Arnaus Gil 2013 and Hager 2014 on early trilingualism). One reason might be that "for the time being, most of us are still working within the theoretical framework of bilingualism" (Hoffmann 1999, p. 16), at least in first language acquisition. Most studies on early child trilingualism underlie the view that it is "another type of bilingualism, and theories and findings from studies of bilinguals are often assumed to be applicable to trilinguals by extension" (Barron-Hauwaert 2000, p. 1; cf. Jessner 1997); however, compare the criticism in Hoffmann (2000). While similarities do exist between early child bilingualism and the acquisition of three languages from birth, "there is still a lack of data comparing bilinguals and trilinguals" (Barron-Hauwaert 2000, p. 2). Hoffmann (2001) also reports differences (cf. also Quay 2011a, 2011b) between early bi- and trilingualism. These observations should invite acquisitionists to consider the necessity of a theory of trilingual first language acquisition, growing apart from bilingual first language theories. The differences between bilinguals and trilinguals are quantitative and qualitative in nature (Hoffmann 2001, p. 1). For example, and in contrast to bilinguals, trilinguals are never assumed to be balanced; there will always be one language which is dominant, while the other two are "weaker" (cf. Montanari 2013, p. 63 for a summary of studies that defend this view). In fact, Montanari (2013, p. 63) argues that the quality of the input (in terms of the 
variety of contacts in the minority language(s) in order to have not only one main language provider, as noted by Barnes (2011)) and language-internal properties play a role in how well each language is mastered by the trilingual child. This brings Quay (2011a, p. 3) to conclude that "trilingual children need to be considered as speakers in their own right". Montanari (2013, p. 63) further considers another reason for the rarity of studies on early child trilingualism, namely the time-consuming and expensive methods that must be used to document language development in trilingual children.

In contrast to young children, speakers who have acquired a third language in adulthood are the subject of several research articles dealing with successive multilingualism under the topic of third language acquisition. Yet, as one reviewer correctly notes, adult L3 acquisition studies are in fact quite limited and restricted to theoretical models that have been proposed in the last 15 years and deal with the initial stages of L3 acquisition. More importantly, third language acquisitionists have developed a sensitivity towards the speaker's chronological acquisition of foreign languages (the first one is called second language, the successive languages L3/Ln). In addition, it matters whether the language learner is bilingual from birth when s/he starts to learn a foreign language, compare the important contributions by Cenoz and Hoffmann (2003), Cenoz and Jessner (2000, 2001a, 2001b, 2001c), and Herdina and Jessner (2002). Simultaneous bilinguals can obtain higher levels of proficiency in the third language than monolinguals who acquired a second and a third language successively. The theories of third language acquisition differ with respect to the role played by the L1 and L2 in L3 learning. The Cumulative Enhancement Model (Flynn et al. 2004) assumes that all previously acquired languages will have a cumulative and positive effect on the learner's L3, making a distinction between first, second, and third language acquisition irrelevant. This assumes that the languages have an additive, positive effect on language learning. ${ }^{1}$ Bardel and Falk (2007), on the other hand, argue in favor of the prominent role of the L2 if learned in a setting comparable to that of the L3 (tutored) within the L2 Status Factor Model. In this case, transfer from the L1 is blocked in L3 acquisition. For Rothman $(2011,2015)$ and his Typological Proximity Model, the language which is (psycho-)typologically similar to the L3 will have a (negative or positive) effect. To sum up, there is currently a lively debate which allows the identification of specific characteristics that distinguish third language from second language acquisition and multilingualism from early bilingualism. This debate is absent when the three first languages are simultaneously acquired (early child trilingualism). It would therefore be interesting and more than relevant to investigate the possibility of an additive effect of the three L1s in the child or, for example, whether the typology of the first and/or second L1 plays an important role in any acceleration in the third L1.

Whereas the research on third language acquisition uses a variety of empirical research methods, early child trilingualism is mainly characterized by longitudinal studies of trilingual children and questionnaires filled in by their parents or so-called parental interviews carried out by linguistic researchers. Quay (2001, p. 157) highlights methodological flaws in studies on early child trilingualism which are still present today: most studies provide minimal, if any, information about their data collection methods, and none of the studies deals systematically with early trilingual development. This is why "we should proceed with caution in evaluating the results from these studies" (Quay 2001, p. 157). The main questions which lie at the heart of early child trilingualism are whether active trilingualism, i.e., the active competence of all three first languages (cf. Chevalier 2015) is possible and what factors increase the likelihood of an active mastery of three languages. In what follows, we will summarize the main studies on trilingual first language acquisition as an illustration of the prevalence of anecdotal descriptions of trilingual language use. These descriptions function mainly as testimonies.

1 As one reviewer correctly remarks, the Cumulative Enhancement Model consequently assumes that non-facilitative transfer should not be observed in the acquisitional L3 data. In order words, negative transfer in L3 acquisition should be absent or explained differently. In fact, many studies on L3 acquisition have presented counter-evidence to this model (e.g., Bardel and Falk 2007 study of the acquisition of negation in L3 Swedish and Dutch). Accordingly, positive transfer is an observable effect of the functioning of the language acquisition device. 
As was the case in the first studies on early child bilingualism (cf. Leopold 1949a, 1949b; Ronjat 1913), there are parental reports (or self-reports) ${ }^{2}$ on language acquisition in early child trilingualism. Some examples are a linguistic diary of the utterances of the researcher's daughter (Dewaele 2000) and Wang (2008) anecdotal report, which is addressed to the parents of trilingual children. These studies show that the simultaneous acquisition of three languages is possible with normal cognitive and linguistic development (Gadler and Mikeš 1986; Mikès 1991; Murrell 1966). Studies of trilingual children often analyze language mixing (Chevalier 2015; Davidiak 2010; Edwards and Dewaele 2007; Hoffmann and Stavans 2007; Ivir-Ashworth 2011; Oksaar 1977; Stavans 1992, 2001; Stavans and Swisher 2006; Widdicombe 1997 as cited by Hoffmann (1999, p. 19ff.; compare also Hoffmann and Widdicombe 1999) and most often language use according to interlocutors (Barnes 2006, 2011; Chevalier 2015, Faingold 1999, 2000). Several factors influence active trilingualism, such as the absence of the community language at home (Braun and Cline 2010, 2014; De Houwer 2004), the mastery of both minority languages by both parents (De Houwer 2004), and the variety of contacts to whom the child is exposed. Chevalier (2015, p. 137) lists eight influencing factors: (1) consistency in following the one-person-one-language strategy; (2) amount of input; (3) language constellations; (4) variety of contacts; (5) variety of media; (6) parental discourse styles; (7) parent is linguist-investigator; and (8) status of the languages involved (Helot 1988; Barron-Hauwaert 2000). In Quay (2008), we learn about the language choices of a trilingual child at 17 dinner sessions from 1;10 until 2;4, i.e., in triadic interaction. Xiaoxiao was raised in Tokyo, Japan, by a Mandarin-speaking mother and an English-speaking father. Quay (2008, p. 30) notes that "she heard English from only $20 \%$ of the input she received in her daily environment", which was enough to mainly use English with her father and not mix more in her weakest language, English. The child's dominant language was Japanese, the language of daycare eight hours each weekday. Xiaoxiao's father spoke English in $90 \%$ of his utterances to his daughter and in $85 \%$ of utterances directed to his wife, while Xiaoxiao's mother spoke Chinese in $90 \%$ of her utterances to her daughter and 80\% of English to her husband. An analysis of Xiaoxiao's mixed utterances "will be reserved for a future paper" (Quay 2008, p. 24), but in general, nouns were mixed (not noun phrases) and content rather than function words figured in mixed utterances.

Rare are the studies which report on trilingual children's development of grammar and vocabulary. Hoffmann (1985) describes her two trilingual German-Spanish-English-speaking children, Cristina (until 8;5) and Pascual (until 5;6). The children heard German from their mother and Spanish from their father, and the family lived in the United Kingdom. They were regularly exposed to English when play-school started at 2;9 (Cristina) and 3;1 (Pascual). Pascual heard the three languages from birth and therefore is an infant trilingual, while Cristina is categorized as an infant bilingual (German, Spanish) and a trilingual (plus English) child (Hoffmann 1985, p. 480). Hoffmann (1985, p. 484) reports divergence from adult German by Cristina, concerning gender, case marking, the use of certain prepositions and conjunctions and word order in German subordinate clauses that exhibit finite verbs in clause-final position, but which show root word order, as in (1) and (2):

1. $\quad 3 ; 7$
das war ich wenn ich war zwei jahre
this was I when I was two years

'This was me when I was two years old.'

2 Elwert [1959] (1973) is a self-report ("Erlebnisbericht" as he writes on p. 274). He describes his own trilingual upbringing first in Italy, then in Germany, by his English-speaking mother and his father who had friends speaking German and Italian to him. It is perhaps due to the fact that the community language was present in the home that Elwert [1959] $(1973$, p. 284) reports that he could not understand the German-speaking doctor of the family when he addressed Elwert at the age of three. German became one of Elwert's languages when the family moved to Germany. This was the case when Elwert was eight years old. 
2. $3 ; 8$

weißt du was kann ich mal machen?

know you what can I PART do?

'Do you know what I can do?'

There are no quantitative analyses, however. Chevalier (2015, p. 126ff.) also finds evidence of cross-linguistic influence in the two German-French-English trilingual children she studied. Examples come from adjective placement in German (only prenominal) and French (both pre- and postnominal positions are allowed): vert couteau 'green knife' (Lina, 3;1,8), vert chofette 'green fork' (=fourchette, Lina, 3;1,8), aff rot 'monkey red' (=Affe, Elliot, 2;5,25), tiger rot 'tiger red' (Elliot, 2;5,25). The two French examples show a prenominal placement of the color adjective vert 'green', which predominantly prefers the postnominal position in the adult language. In adult German and English, however, only the prenominal position of attributive adjectives is possible. The next two German examples from Elliot show a postnominal position which might be due to influence from French. However, there is no quantification at all.

Maneva (2004) describes the language acquisition of her daughter Daria from birth until age 5. Daria grew up in Montreal, where she began French day care at 1;10. Her mother spoke Bulgarian to her and her father Lebanese Arabic. Daria was also in contact with English through visitors, on the radio, on television, etc. At around the age of three, the main language of communication between Daria and her father became French. From the age of 3;11 to 4;6, Daria attended a bilingual French-English preschool. Maneva (2004, p. 112) mentions that Daria used her first two-word utterances which were structured "verb+subject" in Arabic and Bulgarian and "subject+verb" in French as early as 1;7. These results show that Daria was able to produce adult-like subject-verb sequences in all three languages she was in contact with, showing syntactic differentiation.

Mikès (1991) studied lexical differentiation in multilingual children in the town of Novi Sad, where Serbo-Croatian is the dominant language. Three children in her study, Vuk, Uva (siblings) and Egon, (aged 0;10 and 1;11) grew up with Hungarian (the mother's language), Serbo-Croatian (the father's language), and German (the grandmother's language). The children had doublets and triplets in two or three languages (p. 112-13), i.e., they knew the word for a concept in at least two (doublet) or in three (triplet) of their three L1s.

Montanari (2009, 2010a, 2010b) investigated the language choice of a trilingual child named Kathryn who grew up in Los Angeles with her Tagalog-speaking mother and her Spanish-speaking father through diary records and audio recordings from 1;4 until 2;5. English daycare started at age 2;2 (eight hours a day, three days a week), but Kathryn also heard English from her parents and her sister, who was nine years older than her. Both parents were also native speakers of English. ${ }^{3}$ Kathryn differentiated her three lexicons from early on and used 44 doublets and 10 triplets at the end of the study in the appropriate language context. Concretely, the author found that forming a triplet took half the time of learning a doublet, suggesting that adding the word for a concept in the third L1 takes less time than acquiring an equivalent word in the second L1, showing learning facilitation by the same conceptual knowledge (Montanari 2010a, p. 39). Moreover, Kathryn was able to differentiate three phonological systems (cf. Montanari 2011), and word orders (cf. Montanari 2009) in her 438 multi-word utterances: Argument-predicate sequences were differentially ordered depending on the language. Mixed utterances were mainly caused by vocabulary gaps (Montanari 2010b). She concludes that "it is not excluded that increased input diversity leads the child to an enhanced language discrimination capacity and, in turn, to a heightened attention towards

3 Kathryn's mother is Filipino-American, her father Chilean-American. The child's mother came to the United States from the Philippines at age nine; her father moved to Los Angeles from Chile at age twelve. "From birth, Kathryn was addressed primarily in Tagalog by her mother and maternal grandparents, in Spanish by her father and paternal grandmother, and she heard English from her sister, nine years older than herself, and, more indirectly, from family conversations (English was the main medium of communication in the home)" (Montanari 2009, p. 507). 
the structural properties of her languages, thereby enhancing the course and timing of differentiation" (Montanari 2010a, p. 92; cf. also Montanari 2013). In other words, early trilingualism can enhance language acquisition (i.e., acceleration).

Quay (2001) looked at the trilingual language development of a boy named Freddy from 0;11 to 1;10. Freddy grew up in Tokyo with his English-speaking mother, his German-speaking father, and Japanese via daycare. Daycare started at 11 months, but this "late contact" with Japanese played no role in the child's language choice, Japanese being the preferred language from the onset of speech. For her study, Quay (2001) made use of diaries together with the MacArthur Communicative Development Inventory (MCDI, a parental report of the child's understanding and production of the L1s) and video recordings every week. The MCDI was administered every three to four weeks. The main result of this study was that exposure to a third language at the age of 11 months (input delay) does not delay development of that language. "This calls into question distinctions between simultaneous and successive acquisition based on differences in age of exposure", specifically the time between birth and 11 months of age (Quay 2001, p. 195).

Kazzazi (2011) studied cross-linguistic influence in her two children, Anusheh (from the age of 1;0 in the form of notes, audiotapes, and videotapes until 4;9) and Irman (for the latter, only written notes are available). The children were raised in Germany by an English-speaking mother and a Farsi-speaking father. In search of cross-linguistic influence, Kazzazi (2011, p. 65) differentiates between majority and minority influence. Majority influence is observed when two languages share a feature which the third lacks. This feature will then be transferred to the third language. Minority influence takes place "where a feature in only one of the three languages is transferred to the other two languages" (ibid., p. 65). Interestingly, whereas German and English are mainly pre-modifying in attribution structures, Farsi is post-modifying. In German and English, determiners, adjectives, possessives, etc. precede the noun in the noun phrase (NP), while in Farsi, only demonstratives and numerals precede the noun (ibid., p. 67). In Farsi, modifying elements such as attributive adjectives, possessive pronouns, and modifying nouns are linked to the modified element by the so-called ezafe particle (which is often analyzed either as an affix or as a clitic). This particle acts as a default element that links the modifying element to the modified noun. The following examples are taken from Kazzazi (2011, p. 67). They outline that Farsi and English/German are mirror-images of each other for the relevant constructions, namely for attributive adjectives, possessive pronouns, and modifying nouns.

$\begin{array}{rlll}\text { 3. a. } & \begin{array}{l}\text { English } \\ \text { red apple }\end{array} & \text { my apple } & \text { apple-tree } \\ \text { b. } & \begin{array}{l}\text { German } \\ \text { roter apfel }\end{array} & \text { mein apfel } & \text { apfelbaum } \\ \text { c. } & \begin{array}{l}\text { Farsi } \\ \text { sib-e qermez } \\ \text { apple-ezafe red } \\ \text { red apple }\end{array} & \begin{array}{l}\text { sib-e man } \\ \text { apple-ezafe my } \\ \text { my apple }\end{array} & \begin{array}{l}\text { derakht-e sib } \\ \text { tree-ezafe apple } \\ \text { apple tree }\end{array}\end{array}$

These examples illustrate that, if cross-linguistic influence is to be observed by the two trilingual children, it should be majority influence, i.e., if two languages share a linguistic feature not found in the third language (ibid., p. 65). Since both German and English function similarly in terms of attributive constructions as opposed to Farsi, the two Germanic languages would then influence Farsi along these constructions. In other words, prenominal attribution should be found in Farsi. This is what actually happened: at the age of 3;9,17, Anusheh is reported to use prenominal adjectives in Farsi. At the same time, however, she uses English and German compounds that actually are right-headed like the German Lagerfeuer 'bonfire' and the English swimming-bath with the head on the left (feuerlage 'bonfire' and bath-swimming 'swimming bath' at 3;3,14 and 3;3,26, respectively; cf. Kazzazi 2011, p. 70). 
Thus, Anusheh seems to exhibit majority influence in the case of adjective placement, but minority influence in the case of compounds.

To summarize: the studies mentioned clearly demonstrate that it is possible for a trilingual child to reach a native competence level in all three first languages. There are several factors that influence the active production of three languages, yet $20 \%$ of parental input in one of the three languages seems to be enough for the child to become competent in a language. The studies contain evidence in favor of language separation from early on. Cross-linguistic influence is not systematically documented, so one might infer that it is rare in trilingual acquisition. When it does occur, it is not necessarily the dominant language that influences the weak language(s). The effect of trilingualism in the three acquiring languages of the child as opposed to their acquisition in a monolingual and/or bilingual context is completely unstudied. Such a comparison between monolingual, bilingual and trilingual acquisition is needed if the study of a particular grammatical phenomenon is the focus. Our study will contribute to fulfilling this need. We will investigate the phenomenon of French postverbal subjects in early monolingual, bilingual, and trilingual acquisition. The following section will first present the acquisition of French postverbal subjects by monolingual and bilingual children.

\section{Postverbal Subjects in Child French}

Modern French is usually considered a subject-verb-object (SVO) language. Lambrecht (1986) and many others have observed that spoken French is characterized by the dislocation of all kinds of constituents. Constituents can be dislocated to the left, as in (4a) the subject Determiner Phrase (DP), or to the right, as in $(4 b)$.

$\begin{array}{lll}\text { 4. a. Ce livre, } & \text { il est } & \text { très intéressant. } \\ & \text { This book, he is } & \text { very interesting } \\ \text { 'This book, it is very interesting.' } & \end{array}$
b. Il est très intéressant, ce livre.
He is very interesting, this book

'It is very interesting, this book.'

Lambrecht (1986) uses the terms "topic sentence" and "antitopic sentence" for (4a) and (4b), respectively, in which a dislocated element is doubled by a resumptive pronoun in the sentence, expressing person (third person), number (singular), gender (masculine) and case (nominative, cf. 4a,b). Taking into consideration Lambrecht (1986) distinction, Ashby (1982, p. 39), in his study of French word order, found 1355 sentence tokens whose referent is given in the discourse in a corpus of 25 speakers from the age strata of 14-21 years and 51-64 years in and around Tours, recorded in the home or workplace (free conversation). In $83 \%$ of the tokens, the noun phrase that was coreferential with the subject clitic appeared to the left of the finite verb (left-dislocation), while $17 \%$ were of the type in $(4 \mathrm{~b})$ (right dislocation). Notley et al. (2007) confirmed these results. This means that there is a preference for left-dislocations like in (4a) in spoken French. The frequencies, however, vary according to the corpora analyzed. Some authors, like De Cat (2002), observe about 30\% of dislocations in spoken French. Jansen (2015, p. 151) shows that this is also true for child-directed speech, (but cf. Notley et al. 2007, who show the opposite, and van der Linden and Sleeman 2007 for early French).

Following the literature described above, we could assume that we will find left dislocations much more frequently than right dislocations in (French monolingual) child speech. In a seminal article by Déprez and Pierce (1993, p. 42), the authors investigate the productions of monolingual French children until the age of 2;2. They produce constructions like the following in (5), in which a lexical subject occurs in a VOS or a VSO construction, with a finite verb and without a resumptive pronoun that doubles the subject, or with a non-finite verb. During this period, the subject can thus occur in the postverbal position even though no resumptive pronoun that doubles the subject is observed. Notice that transitive as well as intransitive verbs are found in constructions with postverbal subjects. 


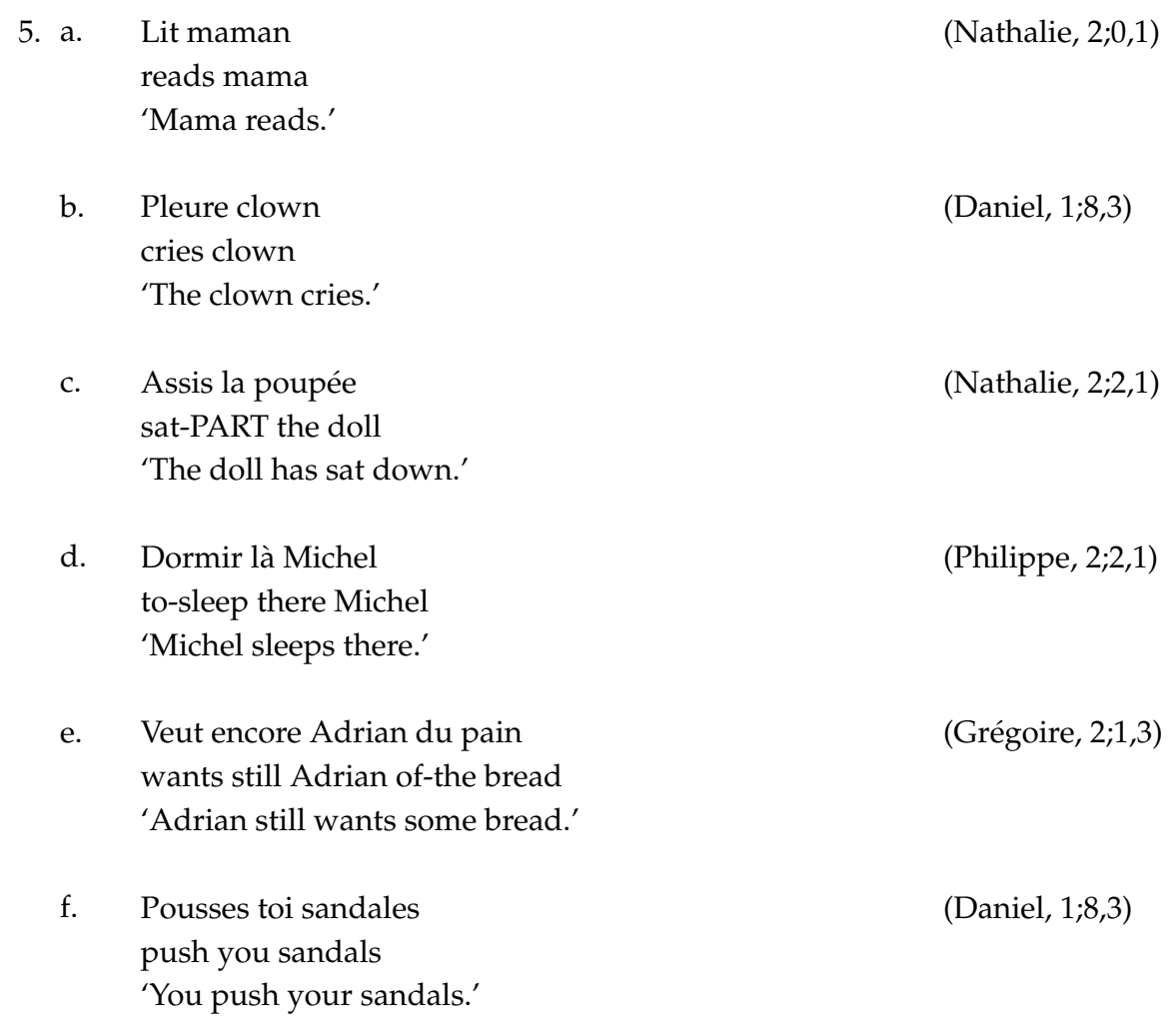

At the same time, the children have target-like utterances which contain a preverbal subject clitic in a finite sentence, like in $(6 a, b)$, a preverbal lexical subject, as in (6c), and a right-dislocated lexical object, like in (6d) (cf. Déprez and Pierce 1993, p. 45 and De Cat 2002, who show that children can use dislocations in a pragmatically proper way). ${ }^{4}$
6. a. Elle dort
She sleeps
'She sleeps.'
b. Il veut un bruit
He wants a noise
'He wants a noise.'
c. Train va tomber
Train falls
'The train falls.'
(Daniel, 1;8,1)
d. Elle la voit l'auto
She it- $\mathrm{Cl}$ wants the car
She wants it, the car.'
(Daniel, 1;11,1)
(Nathalie, 2;2,2)

Déprez and Pierce (1993, p. 42) report a relatively high frequency of constructions like the ones in (5), ranging between $65 \%$ and $85 \%$, in the four children they analyzed from the age of 1;8 onwards.

4 One reviewer points out that subject clitics are categorically absent in the children's structures with postverbal subjects. Indeed, Déprez and Pierce (1993, p. 44) noted that pronominal subjects are absent in the children's untensed clauses and that subject clitics do not appear in the postverbal subject position. The authors explain these results by assuming that subject clitics are affixes in child grammar which are generated in Infl (Inflection) and lexically realized only when bound to a raised verb. Subjects clitics are therefore not equivalent to full NP (Noun Phrase)/DP subjects since they do not parallel the distribution of full NPs/DPs. 
In her analysis of the longitudinal data of three monolingual French children from CHILDES $(1 ; 4-4 ; 10)$ Jansen (2015, chapter 7.1), confining herself to finite clauses, finds evidence of postverbal subjects of the type in (5) in two additional monolingual French children and adds that the postverbal-subject stage ends at the age of 2;7.

Jansen (2015, chp. 7.1) also analyzes the data from five German-French bilingual children in French. Unlike the previous literature, she compares the amount of postverbal subjects on the basis of mean length of utterance (MLU) stages, not on the basis of age. During the whole period of investigation, which comprises 11,087 finite clauses, the monolingual children produced 213 preverbal $(1.92 \%)$ and 130 postverbal $(1.17 \%)$ subjects that were not doubled by a resumptive pronoun. There were 703 empty subjects $(6.34 \%)$. The bilingual children produced 17,969 finite clauses and $177(0.98 \%)$ preverbal, but only $38(0.21 \%)$ postverbal subjects without a doubled resumptive pronoun. There were 603 empty subjects (3.35\%). Postverbal subjects of the type in (5) are ungrammatical in adult French, and thus their absence in the bilingual data indicates the child's convergence to the adult norm.

Jansen (2015) concludes that the absence of postverbal subjects as in (5) in the bilingual data is characteristic of bilingual French (the amount always stays below 5\%), while the monolingual children Madeleine and Philippe evidenced (different) MLU phases during which the amount of postverbal subjects was well above $5 \%$, see Figure $1 .^{5}$

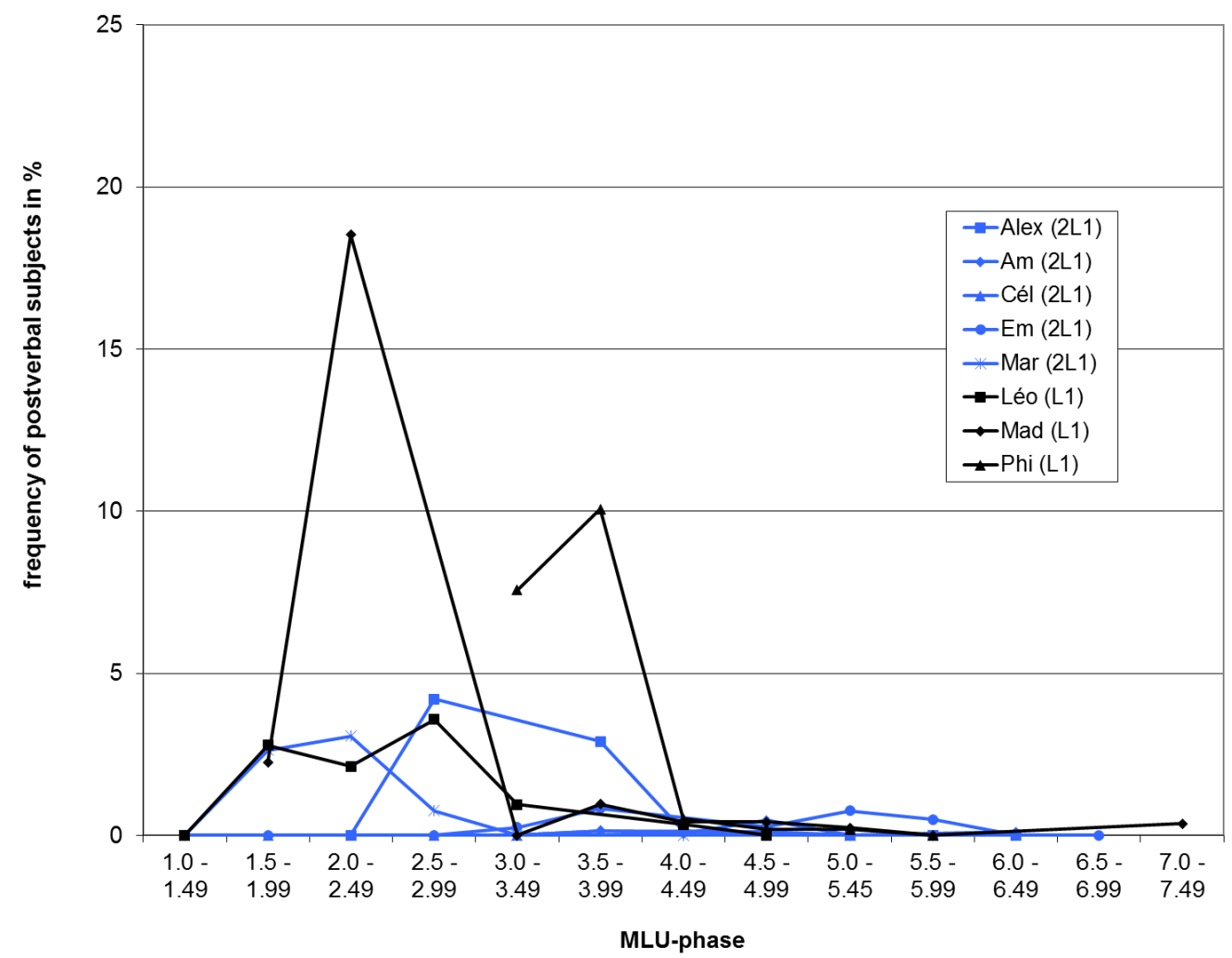

Figure 1. French postverbal subjects according to mean length of utterance (MLU) phase: Monolingual and bilingual children compared (Jansen 2015, p. 255).

5 The monolingual child Léonard differed from his peers: He never reached the $5 \%$-mark for postverbal subjects. Notice, however, that his corpus was small in comparison to that of the other two monolingual children: During the whole period of investigation (1;8,9-3;2,25), he used only 1251 finite clauses (Jansen 2015, p. 137). Philippe uttered approximately four times as many finite clauses during approximately the same period. The difference in the amount of production across children might be seen as part of the children's idiosyncrasies. Notice, however, that it is less likely that a particular target-deviant form appears in a small corpus. 
In order to explain the results observed in monolingual French, Déprez and Pierce (1993) and Friedemann [1993] (1994) proposed the Subject-Raising Failure Approach and argued that postverbal subjects in child French are reminiscent of the child's capacity to raise finite verbs into Infl/Tense (T) in syntax. We have seen that, throughout the whole period of investigation (Jansen 2015), French bilinguals produced less than $1 \%$ of postverbal subjects, and in specific MLU stages where they appeared, they were never greater than $5 \%$. We can thus claim that the postverbal subject stage was absent in the French of the bilingual children. It could be argued that they are accelerated with respect to the knowledge of the ungrammaticality of postverbal subjects which are not doubled by a resumptive clitic. This acceleration effect could be due to the children's second L1, German, which overwhelmingly exhibits subjects in the preverbal position. Notice, however, that the similarity of the two languages must be perused at a deep level of linguistic analysis, since the two adult systems radically differ at the surface. Jansen (2015, p. 154) shows that "dislocations" are very infrequent in spoken adult German (child-directed speech): they amount to 1\%. Furthermore, she argues that "dislocations" to the right are not syntactic dislocations in German, but repairs, in which the speaker uses a lexical subject as a kind of afterthought. In other words, although both languages exhibit preverbal subjects, it is certain that they involve different syntactic machinery for handling the clear differences of their syntax.

Contrary to the Subject-Raising Failure Approach, De Cat (2002), Ferdinand (1993, 1996), and Labelle and Valois (1996) argue that postverbal subjects such as those in (5) in child French are right dislocations without a doubled overt resumptive clitic. During this stage, in which postverbal subjects (which might be analyzed as right dislocations) are produced, null subjects with transitive and intransitive verbs also appear. In a later step, the child thus has to learn that French does not allow null subjects. Under this approach, bilingual children who acquire French and German should be observed to skip the null-subject stage in French. This acceleration effect could be due to the (positive) influence of German, which is a non-null-subject language. Notice, however, that Jansen (2015) and Patuto (2012) observe (target-deviant) null subjects in the bilinguals' French, as well as in their German (Pillunat et al. 2006; Schmitz et al. 2011) until around the age of 2;6. The Right-Dislocation Approach would struggle to explain the simultaneous absence of postverbal subjects and the presence of (target-deviant) null-subjects in bilingual French.

Under both analyses, the Subject-Raising Failure Approach and the Right-Dislocation Approach to postverbal subjects, there is at least one aspect of the child data which is not accounted for, namely the optional character of postverbal subjects, as shown in (5) and (6) above. From the work by Déprez and Pierce (1993) we learn that postverbal lexical subjects co-exist with preverbal lexical subjects. Therefore, we would like to suggest the following analysis of child postverbal subjects, which has the potential to reconcile the many important observations regarding child (monolingual and bilingual) French.

In the vein of the Minimalist Program (Chomsky 1995), Biberauer and Richards (2006) seek to eliminate language-specific properties of the computational system in order to explain alternations in word order within one language which do not go hand in hand with interpretive differences. In the ideal case, different outputs with the same lexical items should have different interpretations, with the exception of the extended projection principle (EPP) feature. This feature is obligatorily present (Chomsky 2013, 2015 for a different view), but languages vary as to the size of the nominal category (the $[D]$ category (nominal category which has the characteristic features of DPs and associates definiteness) raised with or without head/spec-pied-piping) and the source of the nominal category ([D] in a head category or a Spec) that values the EPP feature in T. All that grammar requires is that the T's EPP feature be satisfied; it does not matter how this occurs. A single grammar can therefore contain truly optional structures, i.e., semantically vacuous optionality.

Biberauer and Richards (2006) take the example of Afrikaans, where both the verb-final and the V2 structure (in which the finite verb surfaces in the position preceding the first constituent, irrespective 
of whether this constituent is the subject or has another grammatical function in the clause) receive embedded interpretation.

7. a. Ek weet dat sy dikwels Chopin gespeel het I know that she often Chopin played has

b. Ek weet dat sy het dikwels Chopin gespeel I know that she has often Chopin played

'I know that she has often played Chopin.'

The sentences in (7) share one interpretation. Biberauer and Richards (2006) assume for Afrikaans that the EPP feature in T must be satisfied by an element bearing the categorial feature [D], which is the closest accessible nominal category in T's sister domain. Afrikaans exhibits the EPP feature to be checked by a nominal category, which is either a DP raised into an outer Spec, $v \mathrm{P}$ (specifier of $v \mathrm{P}$, of the small-verb Phrase), the specifier of TP, or by a nominal category which pied-pipes $v$ P into the specifier of TP. In other words, there is either Spec-raising (7b) or Spec-pied-piping (7a). Arnaus Gil and Müller (forthcoming) analyze the alternation of German subordinate clauses (introduced by weil 'because', for example) which can be V2 or V-final (i.e., the finite verb appears clause-finally). In the former case, we are dealing with an instance of Spec-raising of a DP into Spec,TP (specifier of Tense Phrase, as in example (7b)), whereas a V-final structure corresponds to a process of pied-piping of $v \mathrm{P}$ into Spec, $\mathrm{TP}$, as the example in (7a) has shown. The following structures in (8) below show the actual structure of the examples in $(7 \mathrm{a}, \mathrm{b})$ above (cf. Arnaus Gil and Müller forthcoming).

7. a. Structure of an Afrikaans subordinate clause with V2 order

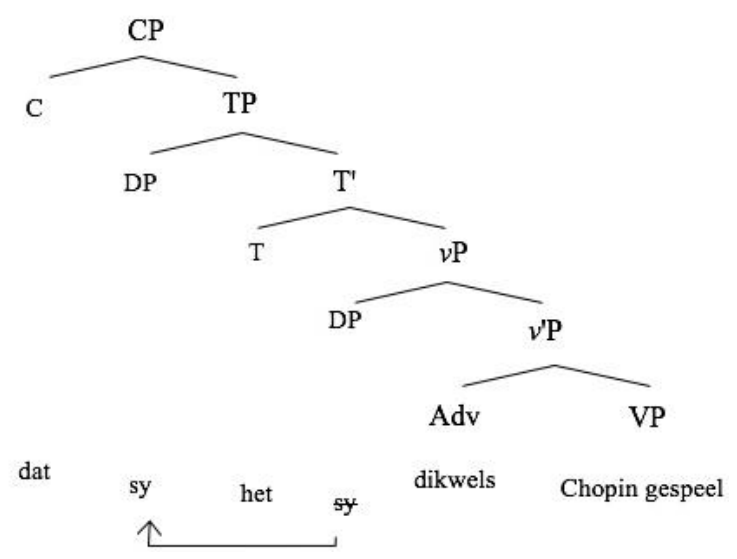

b. Structure of an Afrikaans subordinate clause with V-final order

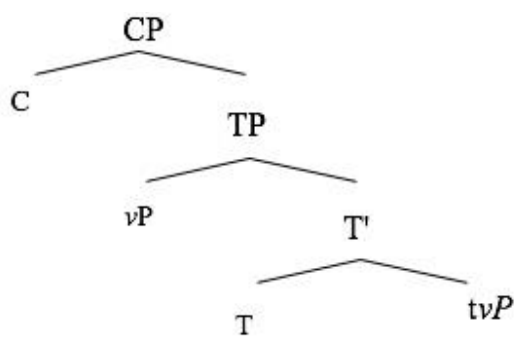

dat $\begin{gathered}\text { sy dikwels } \\ \text { Chopin } \\ \text { gespeel }\end{gathered}$ het

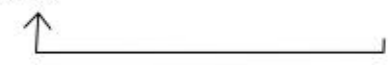


Let us turn to the subject domain in French in the framework of Biberauer and Richards (2006). Adult French in Table 1 is a non-pro-drop language in which an argumental (Spec) DP must obligatorily satisfy the EPP feature in T via Spec-raising. Many Romance languages, such as Italian, Spanish, Portuguese and Catalan, are pro-drop languages in which $V_{D}$ has been argued to satisfy the EPP in $T$ (Alexiadou and Anagnostopoulou 1998). In other words, movement of the finite verb to $T$ suffices in rich agreement languages in order to satisfy the EPP feature. Of course, pro-drop languages also allow DPs in the specifier position of TP (e.g., La ragazza mangia la mela 'The girl eats the apple'), which neither signal a topic shift nor are contrastively stressed. Therefore, EPP satisfaction via Spec-raising is also an option for the adult system of these Romance languages, and it can be carried out by raising a DP into Spec,TP. For adult French, raising of the finite verb into T does not suffice to satisfy the EPP feature in syntax.

Table 1. Typology of extended projection principle (EPP)-in-T (Tense) satisfaction following Biberauer and Richards (2006).

\begin{tabular}{ccc}
\hline $\begin{array}{c}\text { Size/Type of Category } \\
\text { Satisfying the EPP-Feature }\end{array}$ & Type: DP (Determiner Phrase) & Type: V $_{\text {finite }}$ \\
\hline Size: Raising & $\begin{array}{c}\text { French, Afrikaans, German, Italian, } \\
\text { Spanish, Catalan, Portuguese }\end{array}$ & $\begin{array}{c}\text { Italian, Spanish, Catalan, } \\
\text { Portuguese }\end{array}$ \\
\hline Size: Pied-piping & Afrikaans, German & \\
\hline
\end{tabular}

A glance at Table 1 shows that all languages allow the EPP feature in $\mathrm{T}$ to be satisfied via the raising of a DP into Spec,TP. From the perspective of learnability theory, it acts as a default or a subset that all languages take into account.

However, there is another option in French for satisfying the EPP feature of $\mathrm{T}$ that we have not mentioned so far, namely the use of a subject clitic pronoun. Irrespective of how French subject clitics are analyzed with respect to their external categorial and their internal structure in the adult language—see Schmitz and Müller 2008 on the presence/absence of a D-layer and the head/phrase distinction, which is still an ongoing debate-the child needs time to determine the exact nature and function of subject clitics in French. ${ }^{6}$

Summing up: There are different kinds of EPP satisfaction in grammar. Grammar requires the EPP feature to be satisfied, but it does not matter how this occurs. EPP satisfaction in $\mathrm{T}$ is a case of true optionality in grammar. ${ }^{7}$ To put it differently, the EPP feature makes the kind of optionality which is visible in child data possible to grasp, and even predictable.

Monolingual French children who are still in the stage of producing null-subjects, can thus explore raising of a subject DP into Spec,TP and raising the finite verb into T, as adult speakers of Italian, Spanish, or Catalan do (cf. Table 1). The V-raising into T would give rise to postverbal subjects (without a resumptive clitic, of course) in child grammar. We have nothing to say with respect to the possibility of analyzing these postverbal subjects as right-dislocated subjects, since a pragmatically non-neutral subject would be located outside the T-system.

6 Cf. footnote 4. An investigation of the use of subject clitics in child French and in the children studied in the present cross-sectional study is in progress (Stahnke et al. 2018).

7 One reviewer suggests that our analysis has the consequence that the difference between pro-drop and non-pro-drop languages is that pro-drop languages have more options for EPP satisfaction (namely $\mathrm{V}_{\mathrm{D}}$ ). Currently, we have nothing to say about this idea. We included a paragraph on the possibility of satisfying T's EPP feature via a subject clitic. We have seen in the data from the monolingual children that subject clitics are used from early on. The debate on the external and internal syntactic structure of French subject clitics is ongoing. Much relies on the analysis of these clitics. If the subject clitic cannot check off the EPP feature in T, then all sentences which contain a subject clitic without a doubled DP must involve a pro in Spec,TP. If it has the potential to check the EPP feature, it is likely that clitics are merged in T, as in Italian dialects, in which they can be obligatory. We believe that the postverbal subject stage in monolingual French is related to the unclear status of subject clitics in French. Any deeper discussion of this issue is outside the scope of the present article. 


\section{The Study}

\subsection{Participants}

Table 2 illustrates the participants of a cross-sectional study of bilingual, trilingual, and multilingual children who reside in Germany or Spain. ${ }^{8}$ The multilingual children speak more than three languages. The study included 63 children who have acquired French as one of their native languages. The 19 bilingual children range from 3;11-6;4 (mean $=5 ; 0)$, the 38 trilingual children from 2;4-9;3 (mean = 5;0), and the 6 multilingual children from 3;4-6;4 (mean = 4;7). All children participating in the cross-sectional study were actually older than those in the literature. However, there is a relatively high number whose weak language is French, so a comparison can still be carried out with the children presented in the last section. Twenty-three children ranked low in French in the receptive vocabulary test, which we will present further below. The 19 bilingual children were bilingual with French and German $(n=15)$ or French and Spanish $(n=4)$. As can be seen from Table 3, the 44 trilingual and multilingual children spoke French and another Romance language, such as Catalan, Italian, Spanish, Portuguese, Galician, French and German or French and a Romance language and German. Other language(s) that the children learned were Arabic, Dutch, English, and Russian. The heterogeneity of the trilingual group is not relevant for the study of the French postverbal subjects.

Table 2. Children's language combinations in the cross-sectional study.

\begin{tabular}{|c|c|c|c|c|c|c|c|}
\hline Number of Languages & Lang. A & Lang. B & Lang. C & Lang. D & Lang. E & Number of Children & Total \\
\hline Bilingual & French & German & & & & 15 & \multirow[b]{2}{*}{19} \\
\hline Bilingual & French & Spanish & & & & 4 & \\
\hline Trilingual & French & German & Arabic & & & 2 & \multirow{8}{*}{38} \\
\hline Trilingual & French & German & English & & & 18 & \\
\hline Trilingual & French & German & Russian & & & 1 & \\
\hline Trilingual & French & German & Spanish & & & 3 & \\
\hline Trilingual & French & Spanish & English & & & 2 & \\
\hline Trilingual & French & Spanish & Italian & & & 1 & \\
\hline Trilingual & French & Spanish & Catalan & & & 10 & \\
\hline Trilingual & French & Spanish & Russian & & & 1 & \\
\hline Multilingual & French & German & Spanish & English & & 1 & \\
\hline Multilingual & French & German & Spanish & Catalan & & 2 & \\
\hline Multilingual & French & German & Spanish & Dutch & & 1 & \\
\hline Multilingual & French & Spanish & Catalan & Galician & & 1 & \\
\hline Multilingual & French & Spanish & German & English & Arabic & 1 & \\
\hline
\end{tabular}

Table 3. Participation of the children in the cross-sectional study.

\begin{tabular}{cccc}
\hline Type of Multilingualism & Bilingual & Trilingual & Multilingual \\
\hline Grammatical test participation & 19 & 38 & 6 \\
Receptive vocabulary participation & 19 & $37^{9}$ & 6 \\
\hline
\end{tabular}

What is important here is to be able to group the bilinguals, trilinguals and multilinguals according to the subject-type-language they acquire together with French (cf. Tables 1 and 2). Overall, 27 children spoke a null-subject language in addition to French.

8 The study is part of a larger research project which is financed by the German Science Foundation (MU 875/12-1). The parents gave their consent for their children to take part in the study.

9 One of the trilingual children was not tested in the receptive vocabulary task. 


\subsection{Methodology}

We measured language proficiency with the PPVT (Peabody Picture Vocabulary Test, Dunn 1959; Dunn and Dunn 1981, 1997), from which the size of the receptive (hearing) vocabulary can be inferred. The French version of the test was designed by Dunn et al. (1993) and covers a broad range of French-language content words and syntactic categories (adjectives, adverbs, verbs, nouns). Children between the age of 2;6 and 18;0 can be tested. The administration should take 8 to $15 \mathrm{~min}$. It consists of 170 items equally distributed across item sets (one item set contains 12 items). The French PPVT was designed on the basis of a representative sample of 2038 children in Canada. The children came from regions in Canada where English is spoken in addition to French (especially Québec and Ontario). A raw score is transformed into an age-dependent $t$-value which is linguistically described as:

- Extremely high "excellent"

- Moderately high "bon"

- High average "moyen"

- Low average "moyen"

- Moderately low "médiocre"

- Extremely low "faible"

The PPVT is a standardized test designed to analyze vocabulary development in typically developing French-speaking children and used in clinical assessment in order to detect language impairments and school readiness. The test offers a comparison with children who speak French as their native language (control groups) in several age groups. In the present case, it was used to measure linguistic competence in the different L1s of children who acquire more than one language from birth. ${ }^{10}$

The results of the bilingual and the tri- and multilingual children in the French PPVT are summarized in Figures 2 and 3, respectively.

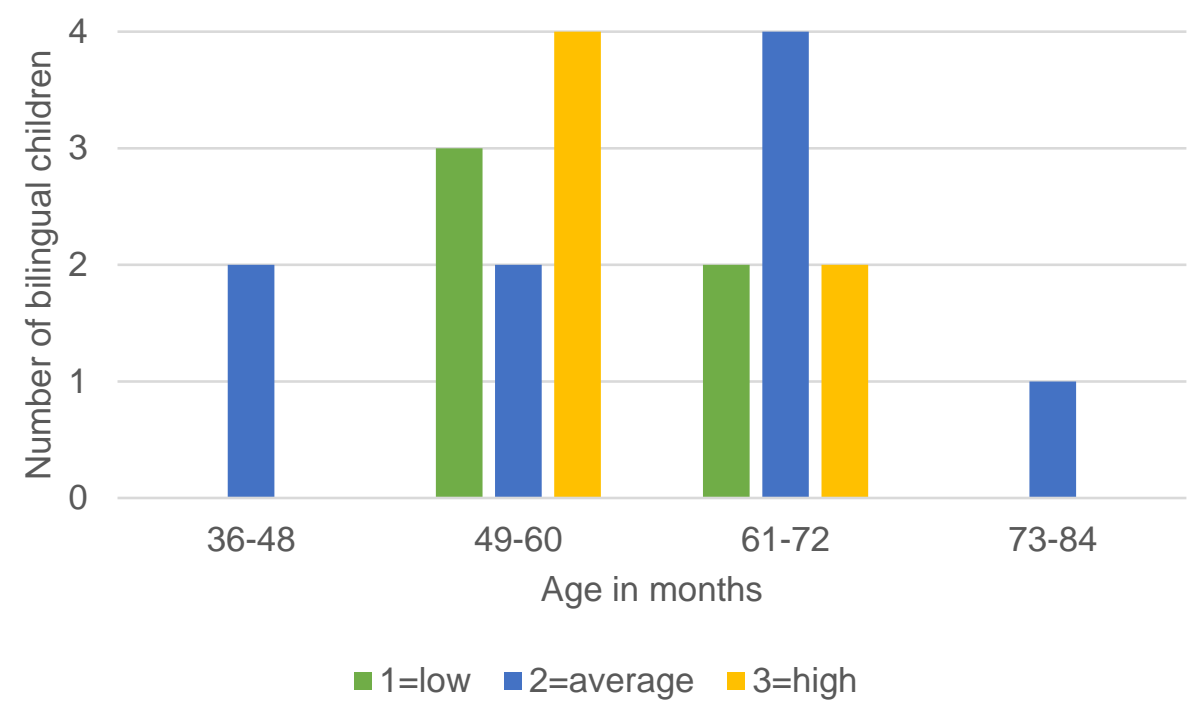

Figure 2. Results in the French Peabody Picture Vocabulary Test (PPVT): bilingual children.

10 The PPVT was used in the languages under study for which this passive vocabulary test is available, that is, for French, German, Spanish and Catalan. 


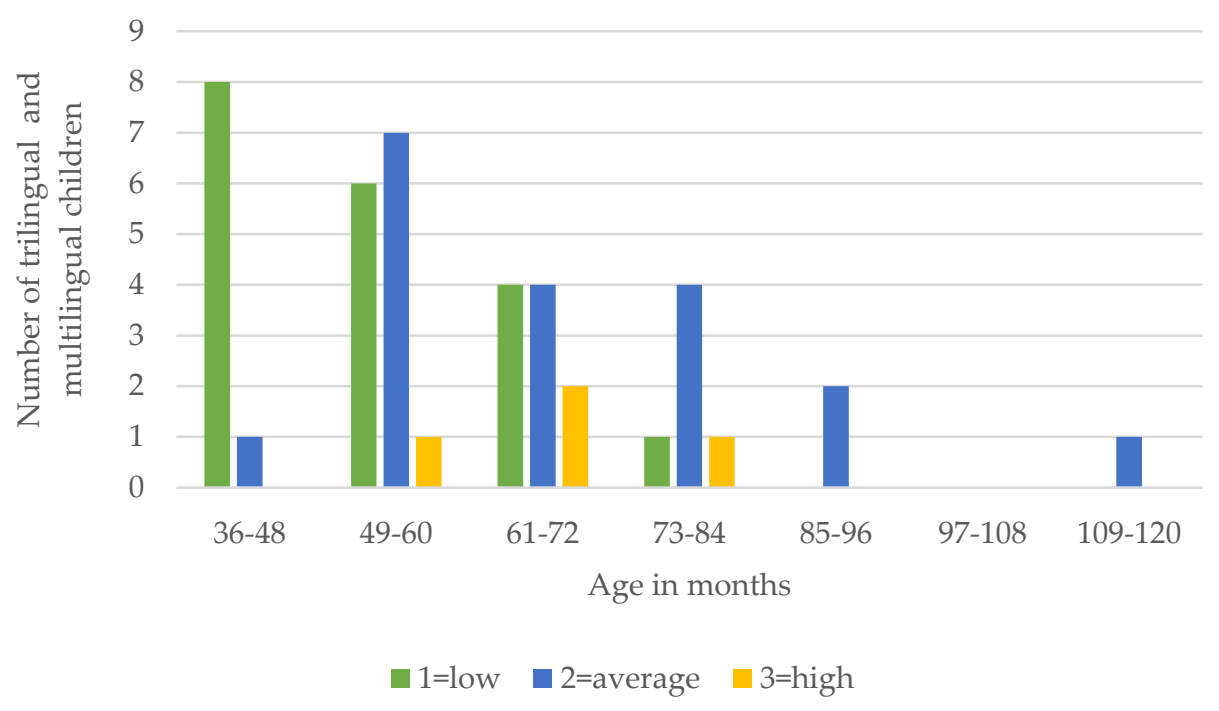

Figure 3. Results in the French PPVT: trilingual and multilingual children.

As can be seen from Figures 2 and 3 above, most bilingual children are in the average group, whereas for the trilinguals and multilinguals, there seems to be a relation between the average and the low group: the older the children get, the better their results in the French PPVT.

In addition to the PPVT, participants also had to complete a production task which aimed to elicit finite verbs and subjects in French. The grammatical test was composed of four cards which showed people performing different actions, all intransitive/unergative in order to guarantee that young children or children with low proficiency in French were able to participate in the test. The test items were the following:

9. a. clown-pleurer

'clown-cry.'

b. garçon-dormir

'boy-sleep.'

c. fille-sauter

'girl-jump.'

d. papi-rire

'grandfather-laugh.'

The clown, the boy, the girl, and the grandfather were introduced to the child on separate cards before the testing began in order to be sure that the child knew the vocabulary used in the test. The child was asked by the experimenter: Dans cette image, qu'est-ce qui se passe? "What is happening in this picture?" to which the child was supposed to answer with a finite clause. Figure 4 illustrates the item of a boy who is sleeping. Notice that we elicited SV structures as can be seen from (9).

We deliberately used SV sentences in order to trigger broad focus and exclude the grammaticality of a right-dislocation with a clitic. Further below, it will become clear that the bilingual children never used a right dislocation as an answer to the experimenter's question, the tri- and multilingual children used it once. De Cat (2002) claims in her work on dislocations that children know from the start of language production which construction to use in which pragmatic context, and she bases her analysis on children's spontaneous data. This also seems to be true for the bi-, tri- and multilingual children in our experiment, since they almost never used a right dislocation. 


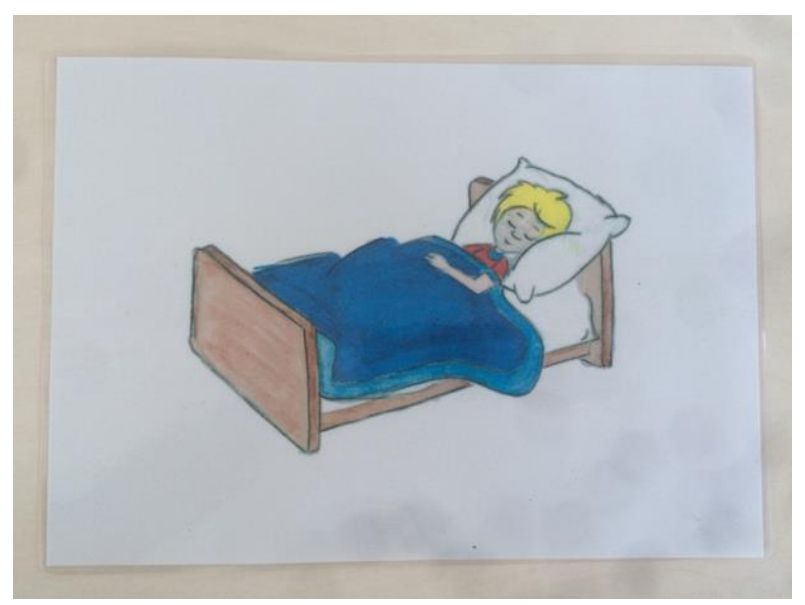

Figure 4. French test item: garçon-dormir 'boy-sleep'.

\subsection{Results}

The French postverbal subject test successfully elicited intransitive verbs. Interestingly, bilinguals produce more intransitives than the tri/multilingual children. This result is illustrated by Figures 5 and 6 .

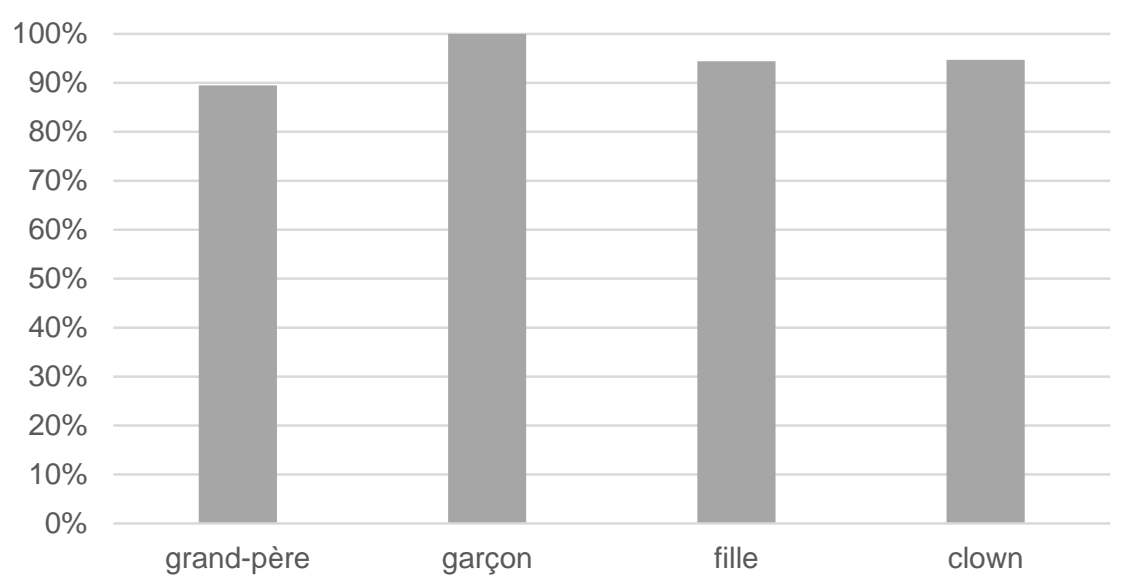

Figure 5. Usage of an intransitive verb per test item: 18 bilingual children.

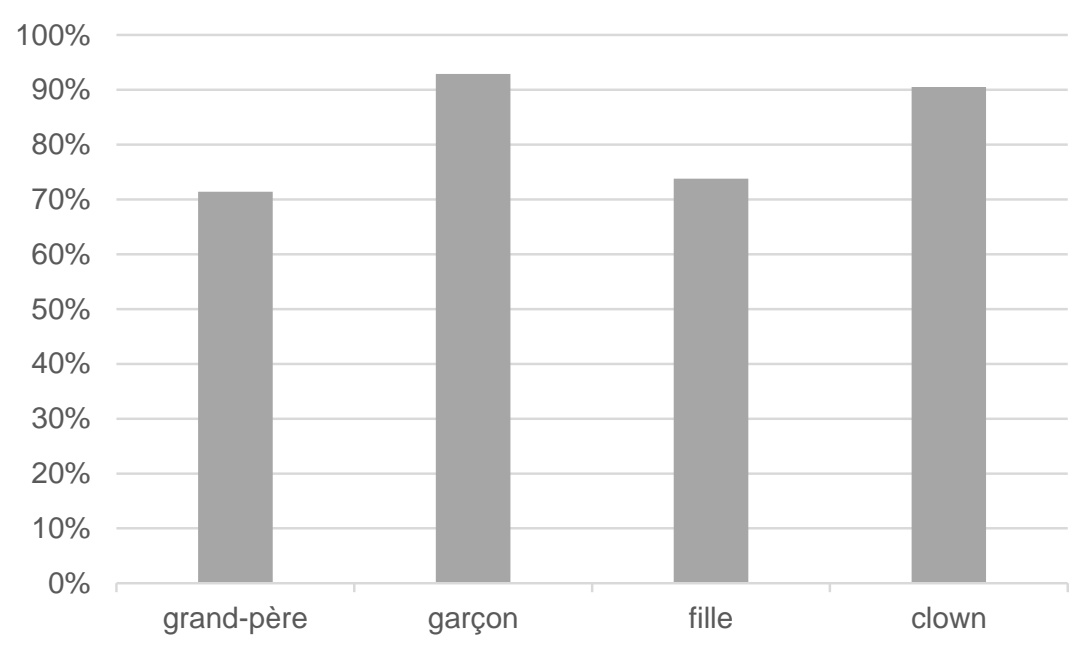

Figure 6. Usage of an intransitive verb per test item: 38 trilingual and 6 multilingual children. 
The most frequent response from the bilingual children was an indefinite DP with a subject relative clause which contained the finite verb. The second most frequent response was a subject pronoun with a finite verb. Figure 7 illustrates the relative frequency of responses from the bilingual children. (10) gives an example of each response type.

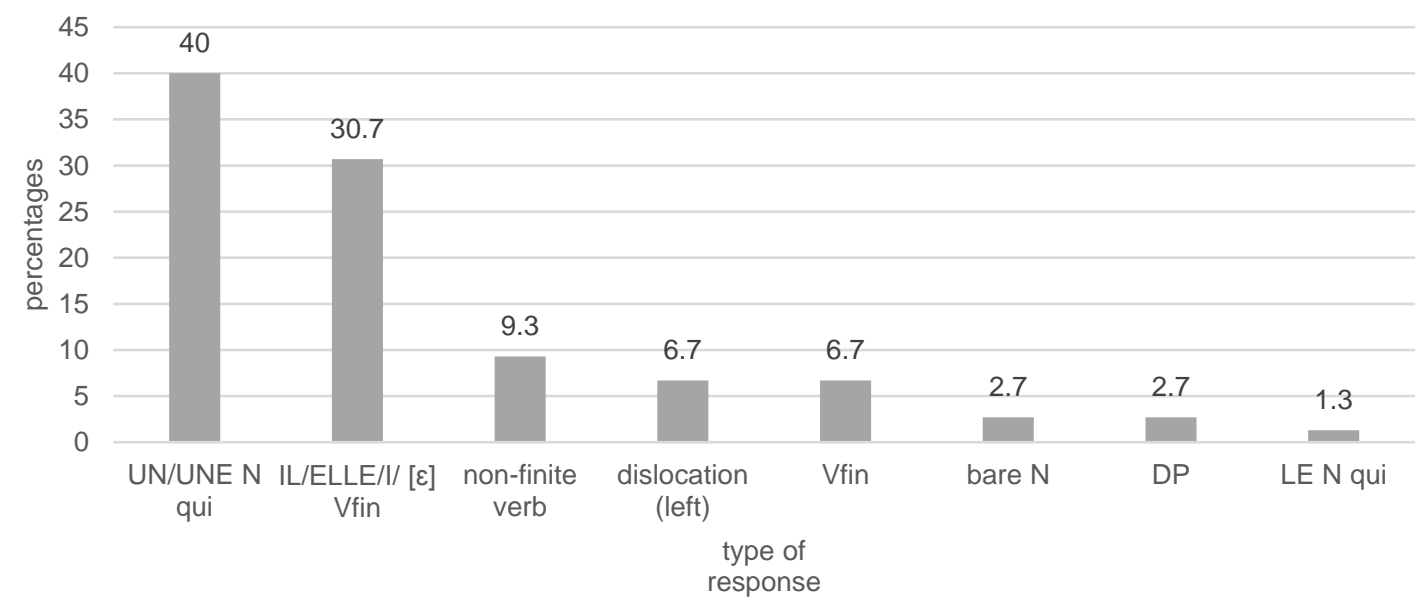

Figure 7. Responses to test items: 18 bilingual children.

10. a. LE N qui Vfin

le garçon qui dort

(Simon, 5;3)

the boy who sleeps

'The boy is sleeping.'

b. UN/UNE N qui Vfin

euh un garçon qui dort

(Delia, 5;7)

a boy who sleeps

'A boy who is sleeping.'

c. IL/ELLE/I/ $[\varepsilon]$ Vfin

elle saute

(Nadette, 3;11)

she jumps

'She is jumping.'

d. Dislocation (left)

le garçon i dortelle saute

the boy he jumps

(Louisa, 5;5)

'The boy, he is jumping.'

e. Bare N

fille

(Yann, 4;3)

girl

f. DP

un clown, tout triste

(Lino, 3;11)

a clown, really sad

g. Vfin with null-subj

rit

(Luca, 4;5)

laughs 
h. Non-finite verb rire laugh-INF

i. UN/UNE N qui Vnon-fin un clown qui qui pleuré a clown who who (has) cried/cry-INF
(Sophie-Alixane, 5;9)

(Fleur, 5;7)

The following Figure 8 shows the percentage of responses for each type, taking into consideration whether the bilinguals acquire German or a Romance language together with French. In other words, taking, for example, the most frequent response in Figure 7 above with $40 \%$ of the total responses, Figure 8 below can be used to determine whether the bilingual group with French-German or the one with French-Spanish showed the same preference. As we can observe, only the former group exclusively answered with UN/UNE N qui. The latter seem to concentrate their answers mainly on responses with finite verbs only, bare $\mathrm{N}$ only, and IL/ELLE Vfin. These observations should be taken with caution, since the French-Spanish group contained only four children.

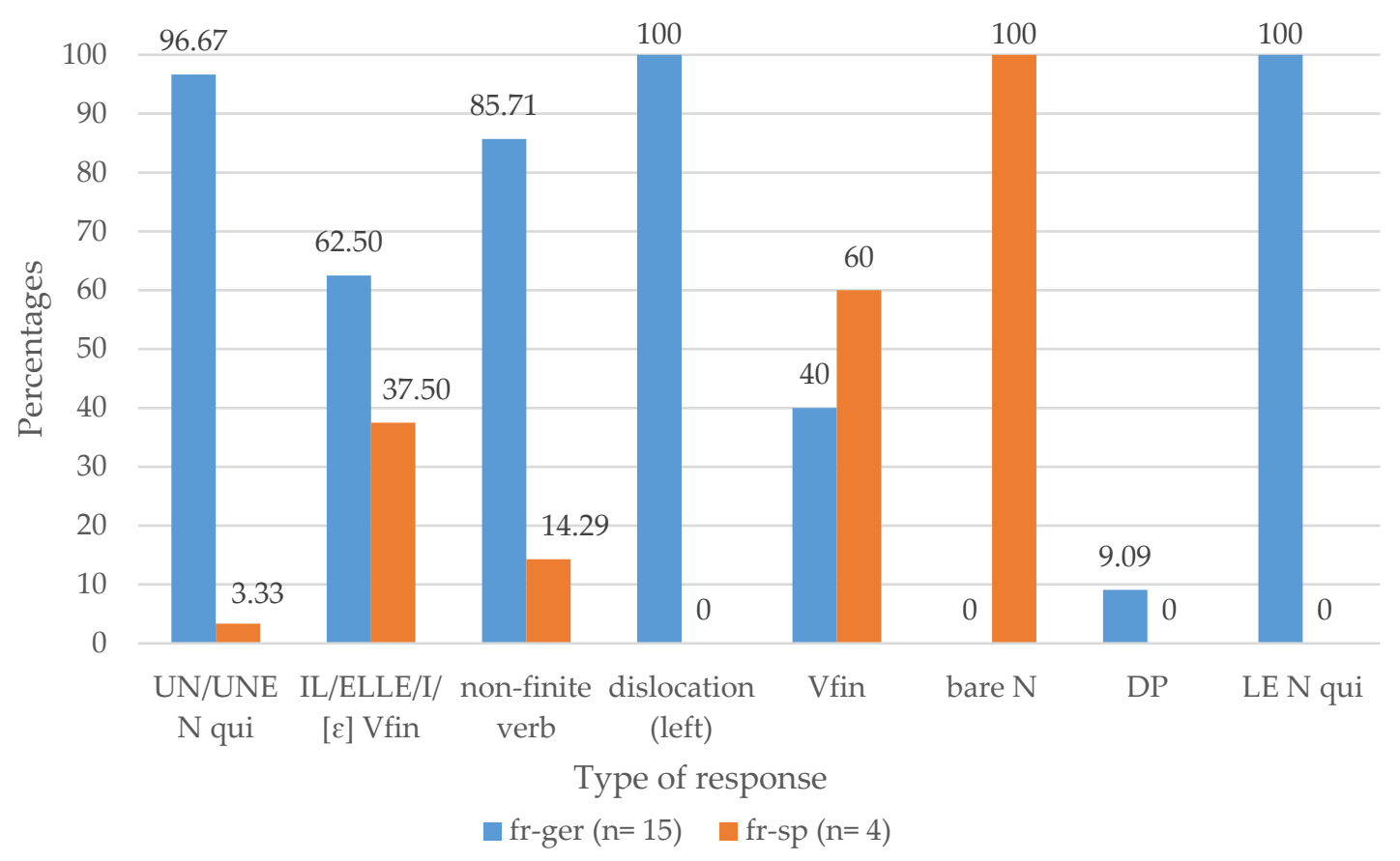

Figure 8. Responses to test items in comparison: bilingual German or Romance together with French.

In the trilingual and the multilingual children, the most frequent response was a subject pronoun with a finite verb, and the second most frequent answer was an indefinite DP with a subject relative clause that contained the finite verb. Remember that these were the same response types we observed for the bilingual group, but their order is reversed. Figure 9 illustrates the relative frequency of the responses of the trilingual and multilingual children. Figure 11 gives an example for each response type that was not used by the bilingual children. 


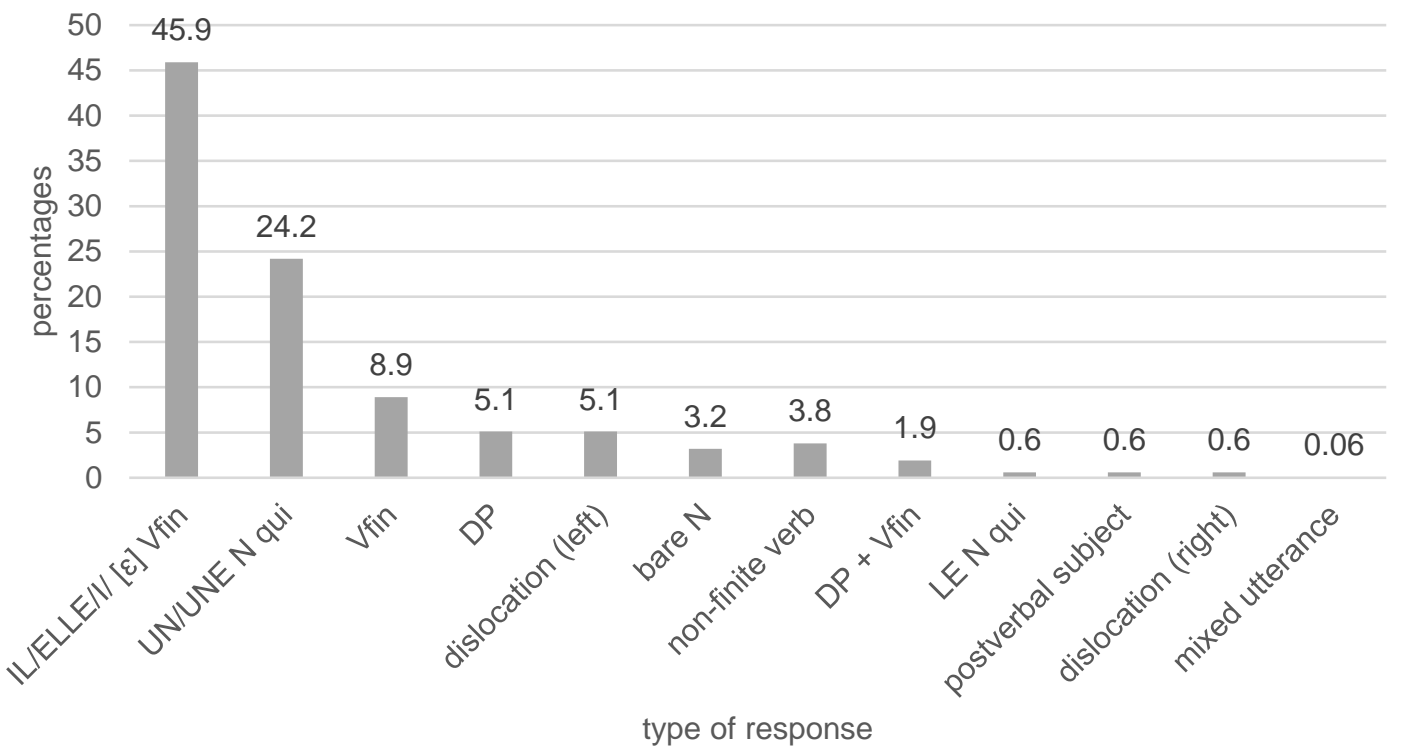

Figure 9. Responses to test items: 38 trilingual and 6 multilingual children.

11. a. Ça Vfin

ça saute

(Emma, 3;9)

it jumps

'It is jumping.'

b. Dislocation (right)

il pleure le clown

(Emma, 3;9)

he cries, the clown

c. Postverbal subject

fait, fille

(Marla, 2;4)

makes, girl

'The girl makes (it).'

d. DP Vfin

la fille saute

(Manon, 5;6)

the girl jumps

'The girl is jumping.'

e. $\quad$ Mixed utterance (German utterance)

schlafen

(Ava, 2;7)

sleep-INF

Figure 10 shows further the percentage of responses for each type, taking into consideration whether the tri-/multilingual children are acquiring German, a Romance language, or both together with French. 


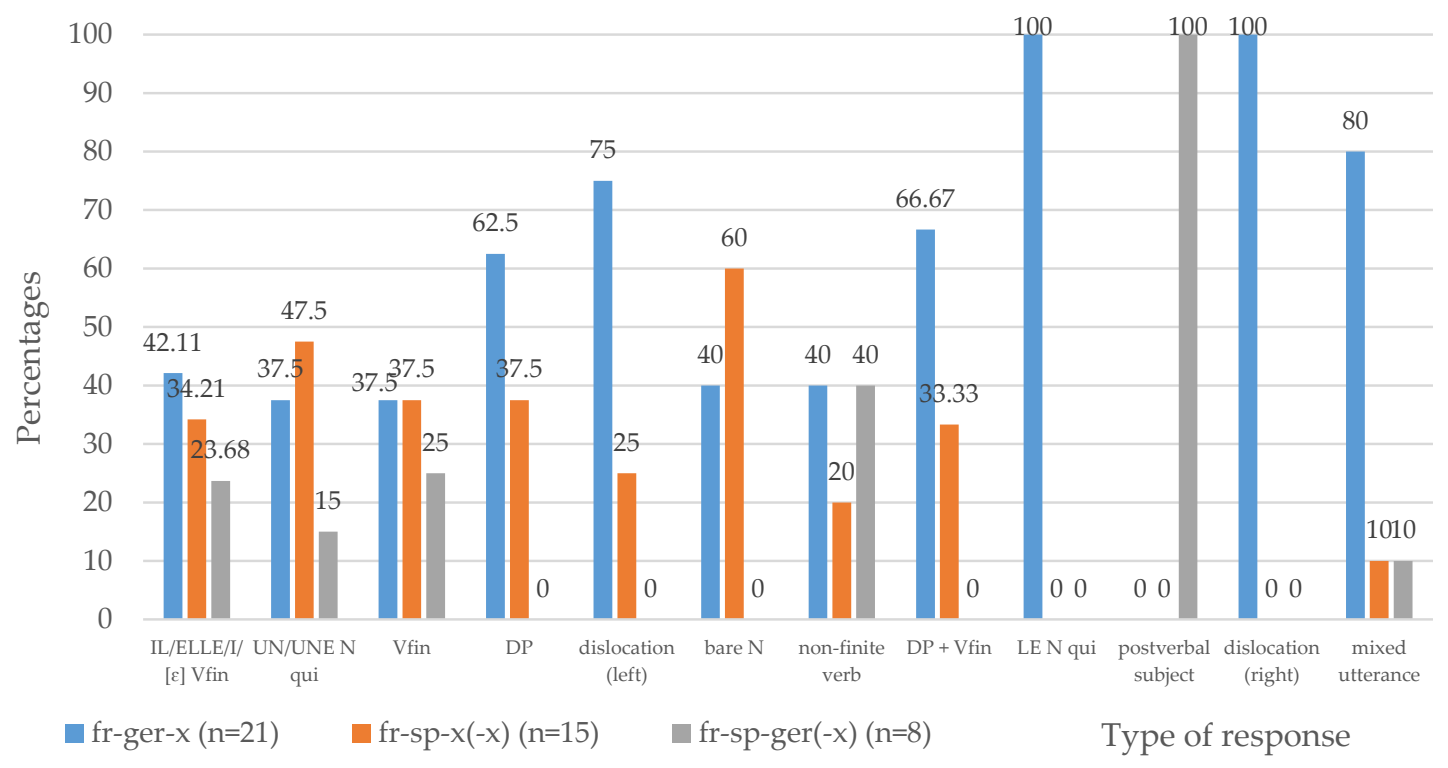

Figure 10. Responses to test items in comparison: tri- and multilingual German and/or Romance together with French.

In comparison to Figure 8 above for the bilinguals, Figure 10 shows a clear tendency for all children in the trilingual groups when it comes to the relative frequency of the most frequent responses in the test, namely subject pronoun+Vfin, indefinite DP+relative clause, and the production of a finite verb. Again, we have seen in Figure 9 that the first type of responses constituted the answer in $45.9 \%$ of the cases. Taking this into account, we see in Figure 10 that all tri- and multilinguals are represented in this response (subject pronoun+Vfin), the second (indefinite DP+relative clause), and the third most frequent answer (finite verb). This result is particularly interesting, since it implies that tri- and multilingual children show a preference for a preverbal subject, irrespective of the language combination, the number of languages (three or more), or the results achieved in the PPVT (cf. Figure 11).

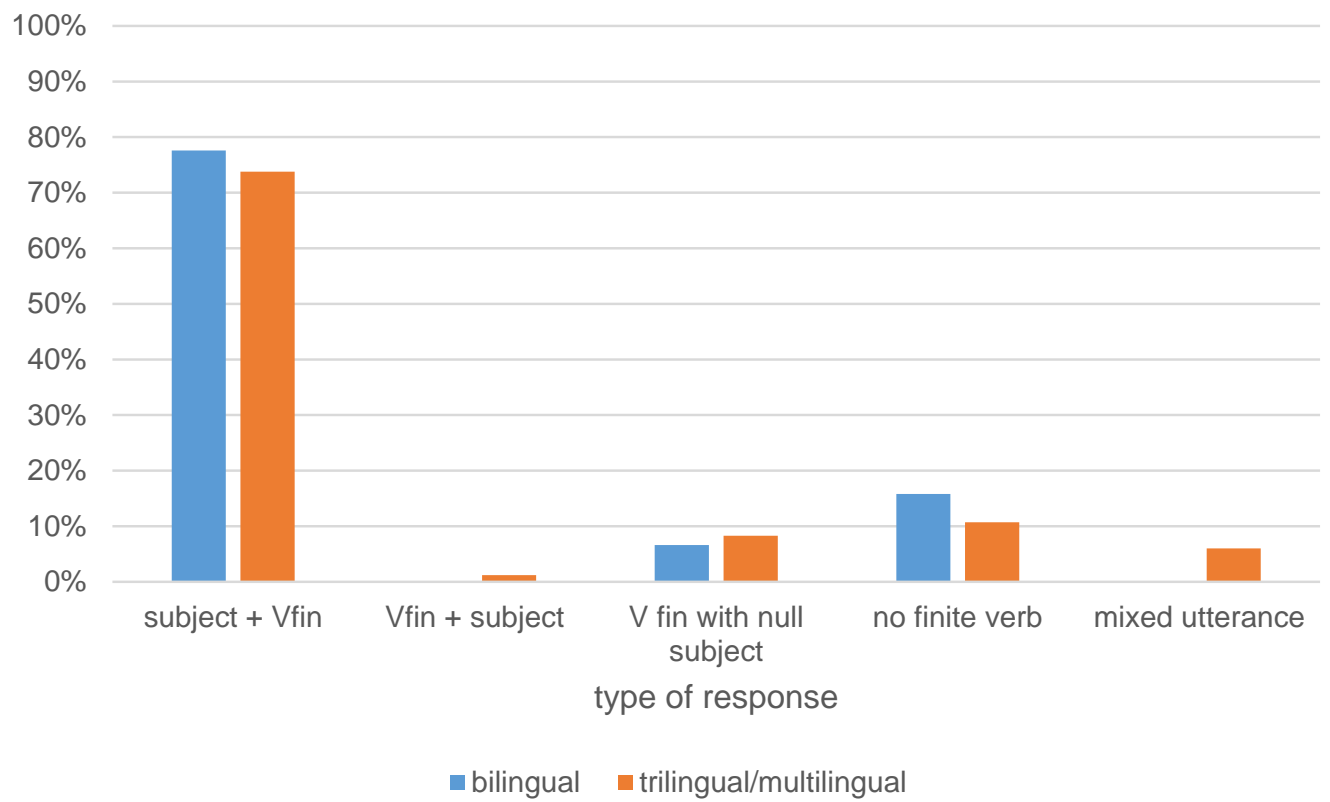

Figure 11. The position of subjects in bilingual, trilingual and multilingual children. 
Figure 11 shows that the bilingual as well as the trilingual and multilingual children strongly preferred preverbal subjects. At the same time, there were bilingual and trilingual/multilingual children who exhibited structures reminiscent of early French: null subjects (10a), utterances which contained a non-finite verb form or no verb at all, and mixed utterances where the child used the non-response language (10e). These children ranked low in the PPVT. Although some structures characteristic of early French occur, there was only one utterance with a finite verb and a postverbal subject among all responses.

Interestingly, as illustrated in Figure 12, there were quite a number of children who ranked low in the French PPVT, in other words, the tested group of trilingual, multilingual and bilingual children contained a fairly high number of children who demonstrated low knowledge in the French receptive vocabulary test. Notwithstanding, the children almost never used postverbal subjects (1 of 487 total responses).

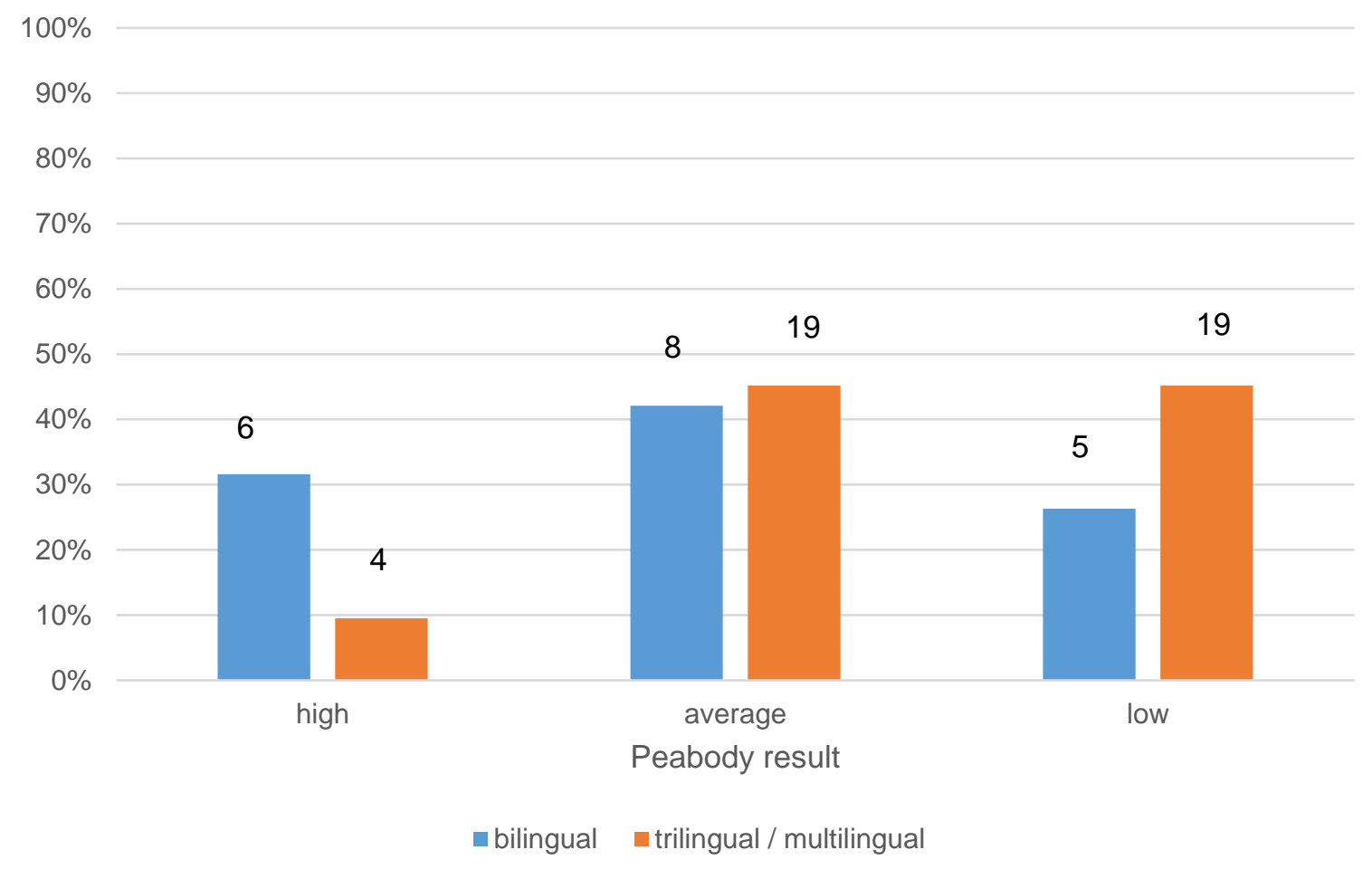

Figure 12. PPVT ranking of bilingual and trilingual/multilingual children compared.

In summary, we can conclude that, although a fairly high number of children ranked low in the PPVT and these children used structures which are reminiscent of an early stage in the development of French, they almost never used postverbal subjects, a structure characteristic of early monolingual French. The absence of postverbal subjects is observed in children who, in addition to French, acquire a spec-seeking language like German, and in children who acquire a null-subject language like Spanish.

\section{Discussion}

The review of the literature on early trilingualism has shown that the field is still in its infancy. Up to now, it has focused primarily on diary recollection. Code-mixing, language preference, and language balance have been issues that have captured linguists' attention in the last few years, but studies often lacked thorough analysis along an age span or among several trilingual children with a similar background. Research on specific linguistic phenomena in early trilingualism is scarce. Our article addresses both of these issues: We analyze a well-studied phenomenon in the early acquisition of monolingual French, namely the acquisition of pre- and postverbal subjects. Previous 
research on this phenomenon with monolinguals and bilinguals has shown that whereas French monolinguals seem to undergo a stage (until 2;7) in which postverbal subjects seem to be one of the possible constructions (among many others, such as subjectless sentences, preverbal subjects and root infinitives), bilingual children acquiring French with German seem to skip this stage with respect to postverbal subjects. Our study contributes to this research field with a cross-sectional study carried out with 62 bilingual, trilingual, and multilingual children who had French as one of their L1s. The study was based on a production task which elicited intransitive subject-verb structures with the aid of visual material. The data show mainly preverbal responses across all children, even those who were classified as having low proficiency in French (according to the PPVT). These results replicate other studies on the acquisition of pre- and postverbal subjects in French in early bilingualism, that is to say, they show no significant amount of postverbal subjects, which seems to speak in favor of a multilingual advantage in acquiring French preverbal subjects.

From a theoretical perspective, we discussed Biberauer and Richards (2006) proposal on true optionality within the possibilities of EPP feature checking in French as well as in German and other Romance languages. Following this idea, we can observe that DP-raising is possible in all languages under study, so we could hypothesize that this is in fact the common ground, that is, the default in the early acquisition of French preverbal subjects. If we are correct, we should be able to claim that a bilingual, trilingual, or multilingual child takes advantage of the possibility of learning more than one L1 in the sense that DP-raising is facilitated and boosts the acquisition of the preverbal subject position in early bilingual, trilingual, and multilingual French. The fact that the children who acquire a null-subject language like Spanish also show the advantage in French indicates that the advantage cannot be explained with the use of the DP-raising analysis in the influencing language, since, after all, about $67 \%$ of all sentences in free conversations among adult native speakers of Spanish (and Italian) contain an empty subject, which underlies a head-seeking grammar $\left(\mathrm{V}_{\mathrm{D}}\right.$ (raised via $v$ ) can satisfy the EPP feature in T). If our syntactic analysis is correct, the children in this study have generalized preverbal subjects due to the default character of DP-raising into Spec,TP. In sum, the bilingual, trilingual, and multilingual children of this study evidence less variability in French than monolingual French children, an observation which goes back to Meisel (1989, p. 27), who observed less word order variability in children who acquire more than one native language.

Can we decide along these lines whether French postverbal subjects are indicative of the Subject-Raising Failure Approach and/or the Right-Dislocation Approach? If young monolingual children produce genuine postverbal subjects (i.e., structures in which finite verb rising into $\mathrm{T}$ suffices to satisfy the EPP feature), our result that bi-, tri-, and multilingual children lack structures which exhibit a postverbal subject may indicate an acceleration of knowledge concerning the subject position in French. However, if monolingual children produce right-dislocated subjects (which lack a resumptive pronoun), the fact that bi-, tri-, and multilingual children do not do so would indicate that they have a disadvantage with respect to monolingual children, who will continue to produce right-dislocations. ${ }^{11}$ We still believe that our approach is neutral with respect to these two approaches for the following reasons: If we assume the Subject-Raising Failure Approach, we could argue within Biberauer and Richards (2006) analysis that a child who fails to raise the subject has under-appreciated the fact that the EPP feature must be satisfied, in this case via spec-seeking. If a bi, tri-, or multilingual child does not use postverbal subjects, but a monolingual child does, it might be argued that the bi-, tri-, or multilingual child is accelerated with respect to EPP satisfaction. If we assume the Right-Dislocation Approach, we could argue within Biberauer and Richards (2006) analysis that a child who fails to produce a clitic has under-appreciated the EPP feature as well, since it must be satisfied, in this case via the merging of a subject-clitic (or via the device which derives subject clitics in French, one of the most controversial topics in French linguistics). Since the focus of our analysis is the optionality of

11 We thank one reviewer for pointing this out to us. 
EPP satisfaction, a discussion of the two approaches to French postverbal subjects in the minimalist framework is outside the scope of our article. Let us not forget that there is still one problem to be solved, a problem which is difficult to solve within generative theory more generally: although the bi-, tri-, and multilingual children were accelerated with respect to postverbal subjects in that they did not produce them, they do not, like their monolingual peers, express a subject in every French finite sentence (in other words, they have subjectless finite sentences). We believe that this observation is completely unexpected under the Right-Dislocation Approach. In order to discuss the underlying syntactic analysis, we would have to focus on empty subjects as well, which, again, lies outside the scope of this study.

Concerning the elicited structures in the study, we deliberately used SV sentences, since they trigger broad focus and therefore a right-dislocation with a clitic would be ungrammatical. The bilingual children never used a right dislocation as an answer to the experimenter's question, and the tri- and multilingual children used one once. De Cat (2002) claims in her work on dislocations that children know from the start of language production which construction to use in which pragmatic context, and she bases her analysis on children's spontaneous data. This also seems to be true for the bi-, tri-, and multilingual children in our experiment, since they almost never used a right dislocation. Put differently, our results could also be argued to show merely that in broad focus contexts, the bi-, triand multilingual children do not produce genuine postverbal subjects, as expected from adult speakers of French. Since we did not test monolingual French children (the research project did not focus on French subjects, but tested several grammatical domains, among them copula use in Spanish and Catalan, adjective placement, and finite verb placement in several languages), and since Jansen (2015) did not analyze the longitudinal data of the monolingual and bilingual French children pragmatically, this interpretation is still possible. ${ }^{12}$

A particularly interesting result of our study is that, according to the literature, French monolingual children show more variability than French-speaking children who acquire more than one language. These observations add to the minimization of external factors such as the amount of exposure (input) in the acquisition process. We believe that the assumption of an EPP feature and its differing satisfaction with a default resource opens the way to a new perspective onto linguistic analyses of multilingualism. Exposure to diversity in the encoding of syntactic relations through the different L1s of the multilingual child may enhance syntactic differentiation, as Montanari (2010a, p. 4) has suggested. This differentiation in the different L1s can be perceived as a drop-out of available options in early language. In other words, children who acquire more than one language receive ideal input from a qualitative perspective. More research is needed to pursue this definitely surprising aspect of the present analysis.

A final note with respect to the syntactic approaches that exist for the description of the postverbal subject stage in monolingual French children is in order. If the present syntactic framework is plausible, monolingual children do not use postverbal subjects due to insufficient syntactic competence, but due to their grammar, which is in its initial stages and therefore allows null-subjects. Put differently, a monolingual French child can explore the raising of a subject DP into Spec,TP (producing a preverbal subject) and the raising of the finite verb into $\mathrm{T}$, resulting either in a subjectless (main) clause or a clause with a subject in the postverbal position. This is a very interesting outcome of our proposal if one considers the fact that a monolingual child receives clearer and more consistent input (where the

12 In other words, we cannot exclude the possibility that our results simply show that children who acquire more than one language know that broad-focus sentences trigger SV. Notice, however, that broad-focus sentences are extremely rare in child spontaneous speech. Therefore, we believe that more research which includes, in addition to cross-sectional data, longitudinal data of bilingual, trilingual, and multilingual children is needed. If broad focus is concerned, more monolingual French corpora should be investigated in future work. Nevertheless, a restriction to the broad focus context was necessary in this experiment to exclude dislocations and cleft-sentences as the children's responses. Future research should also exactly repeat the present production task with monolingual French children. 
subject always raises to Spec,TP). ${ }^{13}$ It remains for future research to implement the scenario depicted for the bi-, tri-, and multilingual children into a theory of first-language acquisition, in particular a theory of a parametrized syntax, namely that a bi-, tri-, or multilingual child can have a grammar which licenses null-subjects, but s/he does not explore all options to satisfy the EPP-feature (in T) as the monolingual child does (thus the lack of postverbal subjects). Put differently, it seems as if only a subset of properties of early (monolingual) French is observed in children who acquire more than one language, if we are on the right track. Since postverbal subjects arguably belong to a cluster of properties in child language, it is interesting that only one property of this cluster differs in children who acquire French together with (an)other language(s). Our research could eventually contribute to the non-parametrized view of the syntactic component in an architecture of the language faculty in which defaults are chosen in bi-, tri-, and multilingual children, all things being equal.

Our research highlights the need for more studies in the field of multilingualism beyond bilingualism with the tools used in longitudinal studies of spontaneous child speech. Furthermore, cross-sectional studies of bilingual, trilingual, and multilingual children should include comparisons with monolingual children.

Author Contributions: L.A.G. conceived and designed the experiments; a group of students all employed by the research project performed the experiments; L.A.G. and N.M. analyzed the data and wrote the paper.

Funding: The grant which made this study available comes from the German Science Foundation (MU 875/12-1).

Acknowledgments: We would like to thank the parents of the tested children who made this research possible. Also, our thanks go to the students who helped with elicitation and who transcribed and double-checked the data.

Conflicts of Interest: The authors declare no conflict of interest. The funding sponsors had no role in the design of the study; in the collection, analyses, or interpretation of data; in the writing of the manuscript; or in the decision to publish the results.

\section{References}

Alexiadou, Artemis, and Elena Anagnostopoulou. 1998. Parametrizing AGR: Word order, V-movement, and EPP-checking. Natural Language and Linguistic Theory 16: 491-40. [CrossRef]

Arnaus Gil, Laia. 2013. La selección Copulativa y auxiliar: Las lenguas romances (español-italiano-catalán-francés) y el alemán en contacto. Su adquisición en niños bilingües y trilingües. Tübingen: Narr.

Arnaus Gil, Laia, and Natascha Müller. forthcoming. Acceleration and delay in bilingual, trilingual and multilingual German-Romance children: Finite verb placement in German. Linguistic Approaches to Bilingualism.

Ashby, William J. 1982. The drift of French syntax. Lingua 57: 29-46. [CrossRef]

Bardel, Camilla, and Ylva Falk. 2007. The role of the second language in third language acquisition: The case of Germanic syntax. Second Language Research 23: 459-84. [CrossRef]

Barnes, Julia D. 2006. Early Trilingualism. A Focus on Questions. Clevedon: Multilingual Matters.

Barnes, Julia D. 2011. The influence of child-directed speech in early trilingualism. International Journal of Multilingualism 8: 42-62. [CrossRef]

Barron-Hauwaert, Suzanne. 2000. Issues surrounding trilingual families: Children with simultaneous exposure to three languages. Zeitschrift für Interkulturellen Fremdsprachenunterricht 5: 1-13.

Biberauer, Theresa, and Marc Richards. 2006. True optionality: When grammar doesn't mind. In Minimalist Essays. Edited by Cedric Boeckx. Amsterdam: Benjamins, pp. 35-67.

Braun, Andreas, and Tony Cline. 2010. Trilingual families in mainly monolingual societies: Working towards a typology. International Journal of Multilingualism 7: 110-27. [CrossRef]

Braun, Andreas, and Tony Cline. 2014. Language Strategies for Trilingual Families. Parents' Perspectives. Bristol: Multilingual Matters.

Cenoz, Jasone, and Charlotte Hoffmann. 2003. Introduction. Acquiring a third language: What role does bilingualism play? International Journal of Bilingualism 7: 1-5. [CrossRef]

13 This issue was pointed out to us by one reviewer. 
Cenoz, Jasone, and Ulrike Jessner, eds. 2000. English in Europe: The Acquisition of a Third Language. Clevedon: Multilingual Matters.

Cenoz, Jasone, Britta Hufeisen, and Ulrike Jessner, eds. 2001a. Third Language Acquisition in the School Context. Bristol: Multilingual Matters, vol. 4.

Cenoz, Jasone, Britta Hufeisen, and Ulrike Jessner, eds. 2001b. Beyond Second Language Acquisition: Studies in triand Multilingualism. Tübingen: Stauffenburg.

Cenoz, Jasone, Britta Hufeisen, and Ulrike Jessner, eds. 2001c. Cross-linguistic Influence in Third Language Acquisition: Psycholinguistic Perspectives. Clevedon: Multilingual Matters.

Chevalier, Sarah. 2015. Trilingual Language Acquisition. Contextual Factors Influencing Active Trilingualism in Early Childhood. Amsterdam: John Benjamins.

Chomsky, Noam. 1995. The Minimalist Program. Cambridge: MIT Press.

Chomsky, Noam. 2013. Problems of projection. Lingua 130: 33-49. [CrossRef]

Chomsky, Noam. 2015. Problems of projection. Extensions. In Structures, Strategies and Beyond: Studies in Honour of Adriana Belletti. Edited by Elisa Di Domenico, Cornelia Hamann and Simona Matteini. Amsterdam: John Benjamins, pp. 1-16.

Davidiak, Elena. 2010. One? ¿Dos? Drei! A Study of Code Switching in Child Trilingualism. Ph.D. dissertation, University of Iowa, Iowa City, IW, USA, May.

De Cat, Cecile. 2002. French Dislocations. Oxford: University of Oxford Dissertation.

De Houwer, Annick. 2004. Trilingual input and children's language use in trilingual families in Flanders. In Trilingualism in Family, School and Community. Edited by Charlotte Hoffmann and Johannes Ytsma. Clevedon: Multilingual Matters, pp. 118-35.

Déprez, Viviane, and Amy Pierce. 1993. Negation and functional projections in early grammar. Linguistic Inquiry 24: 25-67.

Dewaele, Jean-Marc. 2000. Trilingual first language acquisition: Exploration of a linguistic miracle. La Chouette 31: 77-86.

Döpke, Susanne. 1992. One Parent One Language: An Interactional Approach. Amsterdam: John Benjamins.

Döpke, Susanne. 1997. Is simultaneous acquisition of two languages in early childhood equal to acquiring each of the two languages individually? In Proceedings of the 28th Annual Child Research Forum. Edited by Eve V. Clark. Stanford: CSLI Publications, pp. 95-112.

Döpke, Susanne. 1998. Competing language structures: The acquisition of verb placement by bilingual German-English children. Journal of Child Language 25: 555-84. [CrossRef] [PubMed]

Dunn, Lloyd M. 1959. Peabody Picture Vocabulary Test. Circle Pines: American Guidance Service.

Dunn, Lloyd M., and Leota M. Dunn. 1981. Peabody Picture Vocabulary Test-Revised. Circle Pines: American Guidance Service.

Dunn, Lloyd M., and Leota M. Dunn. 1997. Peabody Picture Vocabulary Test, Third Edition. Circle Pines: American Guidance Service.

Dunn, Lloyd M., Claudia M. Thériault-Whalen, and Leota M. Dunn. 1993. Échelle de Vocabulaire en Images Peabody. Toronto: Pearson.

Edwards, Malcolm, and Jean-Marc Dewaele. 2007. Trilingual conversations: A window into trilingual competence? The International Journal of Bilingualism 11: 221-41. [CrossRef]

Elwert, W. Theodor. 1973. Das Zweisprachige Individuum: Ein Selbstzeugnis. Wiesbaden: Franz Steiner Verlag. First published 1959.

Faingold, Eduardo D. 1999. The re-emergence of Spanish and Hebrew in a multilingual adolescent. International Journal of Bilingual Education and Bilingualism 2: 283-95. [CrossRef]

Faingold, Eduardo D. 2000. Pro-active attitudes and educational strategies in early trilingual acquisition: Referential avoidance and parental intervention at the one-word stage. Estudios de Lingüística Aplicada 32: 58-73.

Ferdinand, Renata Astrid. 1993. Subject dislocations in French child language. HIL Manuscripts 1: 54-64.

Ferdinand, Renata Astrid. 1996. The Development of Functional Categories-The Acquisition of the Subject in French. Den Haag: Holland Academic Graphics.

Fernández Fuertes, Raquel, and Juana M. Liceras. 2010. Copula omission in the English developing grammar of English/Spanish bilingual children. International Journal of Bilingual Education and Bilingualism 13: 525-51. [CrossRef] 
Flynn, Suzanne, Claire Foley, and Inne Vinnitskaya. 2004. The cumulative-enhancement model for language acquisition: Comparing adults' and children's pattern of development in first, second and third language acquisition of relative clauses. The International Journal of Multilingualism 1: 3-16. [CrossRef]

Friedemann, Marc-Ariel. 1994. The underlying position of external arguments in French: A study in adult and child grammar. Language Acquisition 3: 209-55. First published 1993. [CrossRef]

Gadler, Hanspeter, and Melaniji Mikeš. 1986. Der Erwerb der Muttersprache beim einsprachigen und beim dreisprachigen Kind. Grazer linguistische Studien 27: 27-43.

Gawlitzek-Maiwald, Ira, and Rosemarie Tracy. 1996. Bilingual bootstrapping. Linguistics 34: 901-26. [CrossRef]

Genesee, Fred. 1989. Early bilingual development: One language or two? Journal of Child Language 16: 161-79. [CrossRef] [PubMed]

Hager, Malin. 2014. Der Genuserwerb bei mehrsprachig aufwachsenden Kindern-Eine longitudinale Untersuchung bilingualer und trilingualer Kinder der Sprachenkombinationen deutsch-französisch/ italienisch/spanisch, französisch-italienisch/spanisch und deutsch-spanisch-katalanisch. Ph.D. dissertation, Bergische Universität Wuppertal, Wuppertal, Germany, July.

Helot, Christine. 1988. Bringing up children in English, French and Irish: Two case studies. Language Culture and Curriculum 1: 281-87. [CrossRef]

Herdina, Philip, and Ulrike Jessner. 2002. A Dynamic Model of Multilingualism. Clevedon: Multilingual Matters.

Hoffmann, Charlotte. 1985. Language acquisition in two trilingual children. Journal of Multilingual and Multicultural Development 6: 479-95. [CrossRef]

Hoffmann, Charlotte. 1999. Trilingual competence: Linguistic and cognitive issues. Applied Linguistic Studies in Central Europe 3: 16-26.

Hoffmann, Charlotte. 2000. Bilingual and trilingual competence: Problems of description and differentiation. Estudios de Sociolingüística 1: 83-92. [CrossRef]

Hoffmann, Charlotte. 2001. Towards a description of trilingual competence. The International Journal of Bilingualism 5: 1-17. [CrossRef]

Hoffmann, Charlotte, and Anat Stavans. 2007. The evolution of trilingual codeswitching from infancy to school age: The shaping of trilingual competence through dynamic language dominance. International Journal of Bilingualism 11: 55-72. [CrossRef]

Hoffmann, Charlotte, and Steve Widdicombe. 1999. Code-Switching and language dominance in the trilingual child. In AILE Actes du $8^{e}$ Colloque EUROSLA Paris, Vol. 1: La Personne Bilingue. Edited by Susan Foster-Cohen, Monique Lambert, Clive Perdue and Rebekah Rast. Paris: Université Paris VIII, pp. 51-62.

Hulk, Aafke, and Natascha Müller. 2000. Cross-linguistic influence at the interface between syntax and pragmatics. Bilingualism: Language and Cognition 3: 227-44. [CrossRef]

Ivir-Ashworth, Ksenija Corinna. 2011. The Nature of Two Trilingual Children's Utterances: Growing Up with Croatian, English and German. Ph.D. dissertation, University of East Anglia, Norwich, UK, August 25.

Jansen, Veronika. 2015. Dislokation im bilingualen Erstspracherwerb. Eine Untersuchung am Beispiel deutsch-französischer Kinder. Berlin, München, Boston: de Gruyter.

Jessner, Ulrike. 1997. Towards a dynamic view of multilingualism. In Language Choices: Conditions, Constraints and Consequences. Edited by Martin Pütz. Amsterdam: John Benjamins, pp. 17-30.

Kazzazi, Kerstin. 2011. Ich brauche mix-cough: Cross-linguistic influence involving German, English and Farsi. International Journal of Multilingualism 8: 63-79. [CrossRef]

Kupisch, Tania. 2006. The Acquisition of Determiners in Bilingual German-Italian and German-French Children. München: Lincom Europa.

Labelle, Marie, and Daniel Valois. 1996. The status of postverbal subjects in French child language. Probus 8: 53-80. [CrossRef]

Lambrecht, Knud. 1986. Topic, Focus, and the Grammar of Spoken French. Berkeley: University of California Dissertation.

Leopold, Werner F. 1949a. Speech Development of a Bilingual Child. A Linguist's Record III: Grammar and General Problems in the First Two Years. New York: AMS Press. 
Leopold, Werner F. 1949b. Speech Development of a Bilingual Child. A linguist's Record IV: Diary from Age 2. New York: AMS Press.

Liceras, Juana M., and Raquel Fernández Fuertes. 2018. Subject omission/production in child bilingual English and child bilingual Spanish: The view from linguistic theory. International Journal of Romance Linguistics. [CrossRef]

Liceras, Juana M., Raquel Fernández Fuertes, and Anahí Alba de la Fuente. 2012. Overt subjects and copula omission in the Spanish and the English grammar of English-Spanish bilinguals. On the locus and directionality of interlinguistic influence. First Language 32: 88-15. [CrossRef]

Lleó, Conxita. 2002. The role of markedness in the acquisition of complex prosodic structures by German-Spanish bilinguals. International Journal of Bilingualism 6: 291-313. [CrossRef]

Lleó, Conxita. 2016. Acquiring multilingual phonologies (2L1, L2 and L3): Are the difficulties in the interfaces? In Manual of Grammatical Interfaces in Romance. Edited by Susann Fisher and Christoph Gabriel. Berlin/München/Boston: de Gruyter, pp. 519-50.

Lleó, Conxita, and Margaret Kehoe. 2002. On the Interaction of Phonological Systems in Child Bilingual Acquisition. International Journal of Bilingualism 6: 233-37.

Lleó, Conxita, and Martin Rakow. 2006. The prosody of early two-word utterances by German and Spanish monolingual and bilingual children. In Interfaces in Multilingualism. Edited by Conxita Lleó. Amsterdam: John Benjamins, pp. 1-26.

Maneva, Blagovesta. 2004. 'Maman, je suis polyglotte!': A case study of multilingual language acquisition from 0 to 5 years. International Journal of Multilingualism 1: 109-22. [CrossRef]

Meisel, Jürgen M. 1989. Early differentiation of languages in bilingual children. In Bilingualism Across the Lifespan: Aspects of Acquisition, Maturity, and Loss. Edited by Kenneth Hyltenstam and Loraine K. Obler. Cambridge: Cambridge University Press, pp. 13-40.

Mikès, Melanie. 1991. Some issues of grammatical development in early trilinguals. Anuario de Psicología 48: 29-38.

Montanari, Simona. 2009. Multi-word combinations and the emergence of differentiated ordering patterns in early trilingual development. Bilingualism: Language and Cognition 12: 503-19. [CrossRef]

Montanari, Simona. 2010a. Language Differentiation in Early Trilingual Development. Evidence from a Case Study. Saarbrücken: Verlag Dr. Müller.

Montanari, Simona. 2010b. Translation equivalents and the emergence of multiple lexicons in early trilingual development. First Language 30: 102-25. [CrossRef]

Montanari, Simona. 2011. Phonological differentiation before age two in a Tagalog-Spanish-English trilingual child. International Journal of Multilingualism 8: 5-21. [CrossRef]

Montanari, Simona. 2013. Productive trilingualism in infancy: What makes it possible? World Journal of English Language 3: 62-77. [CrossRef]

Müller, Natascha. 2017. Different sources of delay and acceleration in early child bilingualism. Zeitschrift für Sprachwissenschaft 36: 7-30. [CrossRef]

Müller, Natascha, and Aafke Hulk. 2001. Cross-linguistic influence in bilingual children: Object omissions and Root Infinitives. In Proceedings of the 24th Annual Boston University Conference on Language Development. Edited by S. Catherine Howell, Sarah A. Fish and Thea Keith-Lucas. Somerville: Cascadilla Press, pp. 546-57.

Murrell, Martin. 1966. Language acquisition in a trilingual environment: Notes from a case-study. Studia Linguistica 20: 9-34. [CrossRef]

Nicoladis, Elena. 1999. Where is my brush-teeth? Acquisition of compound nouns in a French-English bilingual child. Bilingualism: Language and Cognition 2: 245-56. [CrossRef]

Nicoladis, Elena. 2003. Cross-linguistic transfer in deverbal compounds of preschool bilingual children. Bilingualism: Language and Cognition 6: 17-31. [CrossRef]

Notley, Anna, Elisabeth van der Linden, and Aafke Hulk. 2007. Cross-linguistic influence in bilingual children: the case of dislocation. In Romance Language and Linguistic Theory 2005, Selected papers from "Going Romance". Utrecht, 8-10 December 2005. Edited by Sergio Baauw, Frank Drijkoningen and Manuela Pinto. Amsterdam: John Benjamins, pp. 229-59. 
Oksaar, Els. 1977. On becoming trilingual. In Deutsch im Kontakt mit anderen Sprachen. Edited by Carol Molony. Kronberg: Scriptor Verlag, pp. 296-306.

Paradis, Johanne, and Fred Genesee. 1996. Syntactic acquisition in bilingual children: Autonomous or interdependent? Studies in Second Language Acquisition 18: 1-25. [CrossRef]

Patuto, Marisa. 2012. Der Erwerb des Subjekts in (Nicht-)Nullsubjektsprachen: die Rolle des Spracheneinflusses und der Sprachdominanz bei bilingual deutsch-italienisch, deutsch-spanisch und französisch-italienisch aufwachsenden Kindern. Tübingen: Narr.

Patuto, Marisa, Valentina Repetto, and Natascha Müller. 2011. Delay and acceleration in bilingual first language acquisition: The same or different? In The Development of Grammar: Language Acquisition and Diachronic Change. Volume in Honor of Jürgen M. Meisel. Edited by Esther Rinke and Tania Kupisch. Amsterdam: John Benjamins, pp. 231-61.

Pierce, Amy E. 1989. On the Emergence of Syntax: A Crosslinguistic Study. Ph.D. dissertation, Massachusetts Institute of Technology, Cambridge, MA, USA, September.

Pillunat, Antje, Katrin Schmitz, and Natascha Müller. 2006. Die Schnittstelle Syntax-Pragmatik: Subjektauslassungen bei bilingual deutsch-französisch aufwachsenden Kindern. Zeitschrift für Literaturwissenschaft und Linguistik LiLi 143: 7-24. [CrossRef]

Quay, Suzanne. 2001. Managing linguistic boundaries in early trilingual development. In Trends in Bilingual Acquisition. Edited by Jasone Cenoz and Fred Genesee. Amsterdam: John Benjamins, pp. 149-99.

Quay, Suzanne. 2008. Dinner conversations with a trilingual two-year-old: Language socialization in a multilingual context. First Language 28: 5-33. [CrossRef]

Quay, Suzanne. 2011a. Introduction: Data-driven insights from trilingual children in the making. International Journal of Multilingualism 8: 1-4. [CrossRef]

Quay, Suzanne. 2011b. Trilingual toddlers at daycare centres: The role of caregivers and peers in language development. International Journal of Multilingualism 8: 22-41. [CrossRef]

Ronjat, Jules. 1913. Le développement du Langage observé chez un Enfant Bilingue. Paris: Champion.

Rothman, Jason. 2011. L3 syntactic transfer selectivity and typological determinacy: The typological primacy model. Second Language Research 27: 107-27. [CrossRef]

Rothman, Jason. 2015. Linguistic and cognitive motivations for the Typological Primacy Model (TPM) of third language (L3) transfer: Timing of acquisition and proficiency considered. Bilingualism: Language and Cognition 18: 179-90. [CrossRef]

Schmitz, Katrin, and Natascha Müller. 2008. Strong and clitic pronouns in the monolingual and bilingual acquisition of French and Italian. Bilingualism: Language and Cognition 11: 19-41. [CrossRef]

Schmitz, Katrin, Marisa Patuto, and Natascha Müller. 2011. The null-subject parameter at the interface between syntax and pragmatics. Evidence from bilingual German-Italian, German-French and French-Italian children. First Language 31: 1-34. [CrossRef]

Stahnke, Johanna, Laia Arnaus Gil, and Natascha Müller. 2018. Subject Clitics in the Acquisition of French: Bilingual and Trilingual Children Compared. Unpublished Manuscript. Wuppertal, Germany: Bergische Universität Wuppertal.

Stavans, Anat. 1992. Sociolinguistic factors affecting codeswitches produced by trilingual children. Journal of Language, Culture and Curriculum 5: 42-53. [CrossRef]

Stavans, Anat. 2001. Trilingual narratives: Relating events in three languages. In Narrative Development in a Multilingual Context. Edited by Ludo Verhoeven and Sven Strömqvist. Amsterdam: John Benjamins, pp. 340-72.

Stavans, Anat, and Virginia Swisher. 2006. Language switching as a window on trilingual acquisition. International Journal of Multilingualism 3: 193-220. [CrossRef]

Unsworth, Sharon. 2013. Current issues in multilingual first language acquisition. Annual Review of Applied Linguistics 33: 21-50. [CrossRef] 
van der Linden, Elisabeth H., and Petra Sleeman. 2007. Clitic dislocation: Evidence for a low topic position. In Linguistics in the Netherlands. Edited by Bettelou Los and Marjo van Koppen. Amsterdam: John Benjamins, pp. $173-87$.

Wang, Xiao-lei. 2008. Growing Up with Three Languages. Birth to Eleven. Parents' and Teachers' Guides. Bristol: Multilingual Matters.

Widdicombe, Susan. 1997. Code-Switching, Coining and Interference in Trilingual First Language Acquisition: A Case Study. Master's thesis, University of Aston, Birmingham, UK.

(c) (C) 2018 by the authors. Licensee MDPI, Basel, Switzerland. This article is an open access article distributed under the terms and conditions of the Creative Commons Attribution (CC BY) license (http:/ / creativecommons.org/licenses/by/4.0/). 